\title{
BACK TO THE FUTURE: KYLLO, KATZ, AND COMMON LAW
}

\section{David A. Sklansky}

If all law seeks to reconcile the future with the past, the effort is especially evident in the law of search and seizure. The text of the Fourth Amendment itself points both forwards and backwards, joining a prohibition of specific past abuses with a broad proscription of any "unreasonable searches and seizures" the future might deliver. Much of the Supreme Court's famously zigzagging jurisprudence of search and seizure can be understood as a continuing debate over how best to harmonize these two orientations. To what extent does the Fourth Amendment set permanent, unchanging limits on the government's investigative authority? To what extent should those limits change as society changes?'

Recently these questions have become more pressing. The atrocities of September 11, 2001, along with many of the law enforcement measures taken in response, have properly prompted wide reconsideration of the appropriate balance between liberty and security in modern-day America. Now

- Associate Dean and Professor of Law, UCLA School of Law. I thank Peter Arenella, Steven Clymer, David Dolinko, Jerry Kang, Tracey Maclin, Richard Seamon, Jeff Sklansky and Eugene Volokh for comments and criticism, and Michelle Cheng and the staff of the Hugh \& Hazel Darling Law Library for research assistance. Funding for this work was underwritten by the National Center for Justice and the Rule of Law at the University of Mississippi School of Law, which is supported by a grant from the Office of Justice Programs at the U.S. Department of Justice (2000-DD-VX-0032). This article was commissioned in connection with a symposium on the Effect of Technology on Fourth Amendment Analysis and Individual Rights, held at the University of Mississippi School of Law in April 2002.

1 See, e.g., Tracey Maclin, The Complexity of the Fourth Amendment: A Historical Review, 77 B.U. L. REv. 925, 926-27 (1997). "In one case, history provides the driving force behind a ruling; in another, it is neglected even though the challenged police conduct is contrary to historical practice. In yet other cases, the meaning and weight of historical precedent sharply divide the Court, leaving readers to wonder why the Court invokes historic rules when modern realities might govern the interactions between the police and the citizenry." Id. 
more than ever, history may seem to offer little guidance on this question. The Framers did not have to worry about airplanes crashing into skyscrapers, or about lethal aerosols sent through the mail. Neither did they have cause to contemplate the proper restrictions on electronic eavesdropping, or on the use of racial profiles by quasimilitary police forces. Looking for advice on these matters in the eighteenth century can seem pointless, but striking the balance between liberty and security without historical perspective may be worse. How else, if not by reference to the past, will we be able to discern the follies of our own day? And what else is a constitution for, if not striking enduring balances?

As the Supreme Court considers these questions in the coming years, among its likely touchstones will be a decision released three months before the terrorist attacks, Kyllo $v$. United States. ${ }^{2}$ The ruling in Kyllo was relatively narrow: police officers need a warrant to aim a thermal imaging device at a house. ${ }^{3}$ Most of the initial reaction to the decision, moreover, focused on its ideological oddity. ${ }^{4}$ The Supreme Court rarely grants criminal suspects a protection previously rejected by five federal courts of appeals and adopted by none. ${ }^{5}$ When Justice Scalia writes the majority opinion in a Fourth Amendment case over a dissent penned by Justice Stevens, the defendant does not usually win. ${ }^{6}$ And it is rare to

2533 U.S. 27 (2001).

- Kyllo, 533 U.S. at 33.

- See, e.g., Alan M. Dershowitz, Curious Fallout from Bush v. Gore, N.Y. TnMES, July 4, 2001, at A15; Patty Reinert, Ruling Limits Heat-Sensing Search, HOUSTON CHRON., June 12, 2001, at A3, available at 2001 WL 3027481.

- See United States v. Kyllo, 190 F.3d 1041 (9th Cir. 1999), rev'd, 533 U.S. 27 (2001); United States v. Robinson, 62 F.3d 1325 (11th Cir. 1995); United States v. Ishmael, 48 F.3d 850 (5th Cir. 1995); United States v. Myers, 46 F.3d 668 (7th Cir. 1995); United States v. Pinson, 24 F.3d 1056 (8th Cir. 1994). But cf. United States v. Cusumano, 67 F.3d 1497 (10th Cir. 1995) (warrantless use of thermal imager violated Fourth Amendment), vacated and decided on other grounds, 83 F.3d 1247 (10th Cir. 1996) (en banc).

"Justice Scalia sometimes sides with the "liberals" when the Supreme Court divides on questions of criminal procedure, but the liberals he sides with almost always include Justice Stevens. See, e.g., County of Riverside v. McLaughlin, 500 U.S. 44 (1991); Maryland v. Craig, 497 U.S. 836 (1990); Nat'l Treasury Employees 
see Chief Justice Rehnquist, Justice O'Connor and Justice Kennedy all join Justice Stevens and side against Justice Scalia. ${ }^{7}$ In each of these respects, Kyllo stood out as peculiar. ${ }^{8}$

Even before September 11, though, it was apparent that Kyllo had significance beyond its narrow holding and beyond its value as a curiosity. ${ }^{\circ}$ And indeed, the Court's reasoning was expansive. Led by Justice Scalia, the majority took the occasion to set ground rules for determining when any new technology of surveillance constitutes a "search" and thus must comply with the requirements of the Fourth Amendment. In doing so, the Court substantially reinterpreted Katz $v$. United States, ${ }^{10}$ perhaps the most influential searchand-seizure decision of the past half-century, and rethought the relationship between the Fourth Amendment and common law, a relationship that over the past decade has come to figure prominently in the Court's approach to the Fourth Amendment. The majority in Kyllo sought to take "the long view," providing broad guidance on applying the Fourth Amendment to changing times. Particularly in the wake of September 11, this is guidance it behooves us to scrutinize.

Union v. Von Raab, 489 U.S. 656 (1989); Arizona v. Hicks, 480 U.S. 321 (1987). When Justice Stevens dissents in a Fourth Amendment case, ordinarily it means the liberals have lost. See, e.g., Illinois v. Wardlow, 528 U.S. 119 (2000); Florida v. White, 526 U.S. 559 (1999). This is particularly true if Justice Scalia has written the majority opinion. See, e.g., Wyoming v. Houghton, 526 U.S. 295 (1999); California v. Hodari D., 499 U.S. 621 (1991); Griffin v. Wisconsin, 483 U.S. 868 (1987).

7 But cf. PGA Tour, Inc. v. Martin, 532 U.S. 661 (2001).

8 Kyllo himself added further color to the case. He is probably the first criminal defendant ever to celebrate his Supreme Court victory with t-shirts offered for sale on his own web site. See http://www.oregonfast.net/-dlkyllo/ tshirt.htm (visited June 23, 2002). "The front of the shirt has Thermal Warning', two AGEMA 210 thermal imagers and the image that the police obtained after shooting Danny's house. The back of the shirt has Remember to turn off your thermal imager without a warrant-Supreme Court June 11, 2001', a picture of Danny and Danny Lee Kyllo-Freedom Fighter." Id.

- See, e.g., Jeffrey Rosen, A Victory for Privacy, Wall ST. J., June 18, 2001, at A18, available at 2001 WL-WSJ 2866886; Kathryn R. Urbonya, The Fourth Frontier, A.B.A. J., Sept. 2001, at 36.

10389 U.S. 347 (1967).

11 Kyllo, 533 U.S. at 40. 
Happily, it turns out to be guidance that is largely sound. But it is also guidance that poses serious questions.

This article examines Kyllo in some detail, focusing on the manner in which the decision revisits the past-both earlier Fourth Amendment jurisprudence and the common-law antecedents of the Amendment itself-with an eye to the future. Part I describes the doctrinal background of the decision: the widely invoked and firmly ahistoric framework established by Katz, the problems the Court has encountered in applying that framework, and the escalating challenge posed to that framework in recent years by the Court's efforts to anchor Fourth Amendment law in eighteenth-century rules of search and seizure. Part II discusses the approach Kyllo took in analyzing these problems: an approach that differs both from the received understanding of Katz and from the view of the Fourth Amendment toward which the Court had increasingly gravitated in recent years, a view I have described elsewhere as "the new Fourth Amendment originalism."12 Kyllo can easily be seen as a repudiation of Katz and a continuation of the originalist turn in search-andseizure law, but $I$ argue that reading is mistaken. In some respects $K y l l o$ is strikingly faithful to Katz: it strongly reaffirms, for example, the Court's holding in Katz that a search requires no trespass or physical intrusion. And the originalism in $K y l l o$ is not the originalism the Court has applied in other recent Fourth Amendment cases. The use of history in Kyllo is looser, and it has a different focus: the Court has shifted its attention, if only temporarily, from the content of eighteenth-century rules of search and seizure to what those rules accomplished. In these respects, the methodology of Kyllo itself represents something of a return to the past-albeit to a past more open to the future.

Part III of the article assesses Kyllo and explores its connotations for the new Fourth Amendment originalism and for the legacy of Katz. The discussion here is necessarily speculative. Drawing lessons from a single decision is always

12 David A. Sklansky, The Fourth Amendment and Common Law, 100 CoLum. L. REv. 1739, 1744 (2000). 
chancy. But if the Court means what it says in Kyllo, the new Fourth Amendment originalism has been modified for the better. Kyllo may also point the way toward a better understanding of $\mathrm{Katz}$, depending on how the Court answers two questions that Kyllo leaves open. The first concerns the measure of Fourth Amendment protection outside of the home. Kyllo treats the home as a special place for Fourth Amendment purposes-hardly a novel proposition for the Supreme Court, but one that throws into doubt not only the reasoning of Katz, as it usually has been understood, but also the narrow holding of the case, that electronic surveillance of telephone conversations constitutes a "search." I argue that the solution lies in recognizing that the Fourth Amendment protects communications as well as places-or, to use a modern metaphor, that virtual places as well as physical places can receive Fourth Amendment protection. The second question Kyllo leaves open is whether devices like thermal imagers are regulated by the Fourth Amendment only so long as they remain uncommon. I argue that the answer should be no, but that defending this answer may require the Court to reconsider certain other features of search-and-seizure law-features that are due for reconsideration in any event.

Throughout this article, I focus on what might be called the temporal orientation of Fourth Amendment jurisprudence: the degree to which the Supreme Court's methodology focuses on the past, the present, or the future. This focus entails two kinds of simplification, and it is well to acknowledge them at the outset.

First, there obviously is a good deal more to search-andseizure law than its temporal orientation. Even leaving aside fine points of doctrine, the story of Fourth Amendment law has important themes other than the relative importance placed on history, present-day realities, and predictions of things to come. There is the question of textualism, for example, a question muted but hardly settled by the famously open-ended wording of the Fourth Amendment. There is also the debate between rules and standards, the pervasive issues of race and class-and, of course, the inevitable tradeoffs 
between liberty and security. ${ }^{13}$ I focus here on the temporal orientation of search-and-seizure law not because it is the law's single most critical feature, but because it has received less attention than other aspects of Fourth Amendment jurisprudence, and because, as I hope to show, it proves especially helpful in assessing the significance of $K y l l o$.

Second, even to speak of the law's temporal orientation is necessarily to leave out certain nuances-so much so that the entire enterprise may at first strike the reader as unintelligible. Most people, and most Supreme Court Justices, would say that any sensible application of the Fourth Amendment needs to take into account historical background and modern conditions and anticipated developments. Thus, for example, Chief Justice Taft wrote for the Court in Carroll $v$. United States ${ }^{14}$ that the Amendment should be read in the light of what was deemed an unreasonable search and seizure when it was adopted, and in a manner which will conserve public interests as well as the interests and rights of individual citizens." ${ }^{15}$ Justice Brandeis, in his famous dissent in Olmstead $v$. United States, ${ }^{16}$ sought to draw from the eighteenth-century origins of the Fourth Amendment a principle supple enough to keep pace with the "progress of science in furnishing the Government with means of espionage." ${ }^{17}$ And Justice Scalia's majority opinion in Kyllo tried to work "from the original meaning of the Fourth Amendment forward." ${ }^{\text {As }}$

Still, some views of the Fourth Amendment seem to lean particularly heavily on the past, while others focus with special intensity on the present or the future. The last decade of search-and-seizure law has in fact been marked by a struggle between a view of the first kind and a view of the second kind. And part of what makes Kyllo important is

13 The classic exposition of these tensions remains Anthony G. Amsterdam, Perspectives on the Fourth Amendment, 58 MrNN. L. REv. 349 (1974).

${ }^{14} 267$ U.S. 132 (1925).

1s Carroll, 267 U.S. at 149 (emphasis added).

${ }_{16} 277$ U.S. 438 (1928).

17 Olmstead, 277 U.S. at 474.

18 Kyllo, 533 U.S. at 40. 
precisely the manner in which it grows out of and alters the terms of that struggle.

\section{THE CONTEXT OF KYLLO}

In the fifty years before it decided Kyllo $v$. United States, the Supreme Court had twice significantly altered its approach to the Fourth Amendment and, in particular, the role of history in interpreting the Amendment. The first change was signaled by the Court's consciously modernizing decision in Katz v. United States. The second change cannot similarly be traced to a particular, pivotal case, but instead was accomplished gradually, through a series of decisions placing increasing emphasis on eighteenth-century common law as a guide for applying the Fourth Amendment. These are the cases I have described elsewhere as announcing a new Fourth Amendment originalism.

Understanding Kyllo requires an appreciation of both these earlier developments-Katz and the return to common law. In important ways, Kyllo steers a middle course between them. Before discussing Kyllo, therefore, let us examine its context.

\section{A. Katz}

The central question of Fourth Amendment jurisprudence has always been what to make of the broad prohibition, in the Amendment's opening clause, of all "unreasonable searches and seizures" of "persons, houses, papers, and effects." ${ }^{\text {"19 }}$ The Amendment's second, concluding clause is much less sweeping; it directs only that warrants must be based on "probable cause, supported by Oath or affirmation," and must "particularly describ[e] the place to be searched, and the persons or things to be seized."20 The wording of the second clause leaves open certain important questions, notably what counts as "probable cause" and what degree of "particularity" warrants must satisfy. But these are relatively narrow inquiries,

U.S. CoNST. amend. IV.

${ }^{20}$ Id. 
and the Supreme Court has made them simple by keeping the definition of probable cause exceedingly vague ${ }^{21}$ and the standard of particularity exceedingly low. ${ }^{22}$ The difficulty in Fourth Amendment law is defining "unreasonable searches and seizures."

The challenge is twofold: defining "searches and seizures" and deciding what makes a search or seizure "unreasonable." Of these, the first is as important as the second, and arguably more important. For any standards of reasonableness inevitably will have some play, allowing courts to strike down those searches and seizures that seem particularly abusive and uphold those that seem particularly justified. But investigative tactics that are not deemed "searches" or "seizures" escape judicial review altogether under the Fourth Amendment. And, conversely, once something is declared a "search" or "seizure" for purposes of the Amendment, it becomes the business of courts to decide its reasonableness, intruding on and possibly second-guessing the judgment of the police.

For roughly the first two-thirds of the twentieth century, the Supreme Court relied in part on the history of the Fourth Amendment for assistance in answering both of the definitional problems associated with the term "unreasonable searches and seizures." The chief evils against which the Amendment took aim were the "general warrants" that English judges had struck down in a celebrated series of decisions in the 1760s and the "writs of assistance" to which the American colonists had repeatedly protested in the years leading up to the Revolutionary War. ${ }^{23}$ Both these instruments autho-

21 See, e.g., Illinois v. Gates, 462 U.S. 213 (1983); Draper v. United States, 358 U.S. 307 (1959). The sole complication in the definition of probable cause is the manner in which the standard is relaxed for administrative warrants. See Camara v. Municipal Court, 387 U.S. 523 (1967). The Court has resolutely refused to extend the relaxed standard, or even the notion that the standard of probable cause can be relaxed, to any other setting. See, e.g., Griffin v. Wisconsin, 483 U.S. 868, 877-78 (1987).

${ }_{27}$ See, e.g., Andresen v. Maryland, 427 U.S. 463 (1976).

2s General warrants were expansive grants of authority to crown officers to search for and to arrest certain offenders, typically printers and publishers of seditious libel, and to search for and to seize their papers. Writs of assistance empowered colonial revenue agents to search for smuggled goods wherever they 
rized entry into homes and the seizure of papers and effects. Partly for this reason, and notwithstanding the protests from Justice Brandeis, the Supreme Court ruled early in the twentieth century in Olmstead $v$. United States that a "search" or "seizure" for purposes of the Fourth Amendment must involve a physical trespass or confiscation. ${ }^{24}$ And because both general warrants and writs of assistance were attacked as abuses of the warrant process, the Supreme Court concluded that adherence to that process should ordinarily serve as the benchmark for determining whether a search or seizure is "reasonable" for purposes of the Fourth Amendment. Therefore the Amendment's broad prohibition of "unreasonable searches and seizures" became, to a large extent, a rule requiring that any search or seizure, subject to certain exceptions, be authorized by warrant and supported by a showing of probable cause. ${ }^{25}$

When the Supreme Court decided Katz in 1967, it left

might be hidden. For discussions of general warrants and writs of assistance, the resentment they provoked, and their role in the development of the Fourth Amendment, see, for example, NELSON B. LASSON, THE HISTORY AND DEVELOPMENT OF THE FOURTH AMENDMENT TO THE UNITED STATES CONSTITUTION 42-78 (1937); TELFORD TAYLOR, Search, Seizure, and Surveillance, in Two STUDIES IN CONSTITUTIONAL INTERPRETATION 19, 24-38 (1969); Thomas Y. Davies, Recovering the Original Fourth Amendment, 98 Mich. L. REv. 547 (1999); Maclin, supra note 1, at 939-50; William J. Cuddihy, The Fourth Amendment: Origins and Original Meaning 884-1181 (1990) (unpublished dissertation, Claremont Graduate School). For a helpful summary of Cuddihy's work and a thoughtful assessment of its implications, see Morgan Cloud, Searching Through History; Searching for History, 63 U. CHI. L. REV. 1707 (1996).

24 277 U.S. 438, 463-66 (1928).

${ }^{25}$ See, e.g., TAYLOR, supra note 23; Akhil Reed Amar, Fourth Amendment First Principles, 107 HARV. L. REV. 757, 762-85 (1994). The claim should not be overstated. The Court sometimes wavered from the warrant requirement, perhaps most notably in a string of vacillating decisions about searches following lawful arrests. At one point, the Court tied the validity of such searches to "the total atmosphere of the case" and held that "[t]he relevant test is not whether it is reasonable to procure a search warrant, but whether the search was reasonable." United States v. Rabinowitz, 339 U.S. 56, 66 (1950). But this position marked a departure from the Court's previous insistence that, even for searches incident to arrest, "[i]t is a cardinal rule that .. . law enforcement agents must secure and use search warrants wherever reasonably practicable." Trupiano v. United States, 344 U.S. 669 (1948). And the Court ultimately repudiated both the holding and the underlying approach of Rabinowitz. See infra note 26. "The warrant requirement," the Court later explained, "has been a valued part of our constitutional law for decades." Coolidge v. New Hampshire, 403 U.S. 443, 481 (1971). 
untouched-for the time being-the principle that "unreasonable" for purposes of the Fourth Amendment generally meant "without probable cause and a warrant." Indeed, Katz expressly reaffirmed that "searches conducted outside the judicial process, without prior approval by judge or magistrate, are per se unreasonable under the Fourth Amendment-subject only to a few specifically established and well-delineated exceptions. ${ }^{26}$ But while Katz retained the traditional definition of reasonableness, the decision appeared to revolutionize the test for determining in the first place whether something is a "search" or "seizure," and thus subject to the Fourth Amendment. The "trespass" test had led the Court in Olmstead to conclude that wiretapping fell outside the ambit of the Fourth Amendment because it involved neither physical entry into the suspect's house nor an actual confiscation of the suspect's property. ${ }^{27}$ At issue in Katz was electronic monitoring of calls placed by a bookie from two telephone booths. ${ }^{28}$ Under Olmstead this clearly was neither a search nor a seizure: nothing tangible was confiscated, and there was no trespass. ${ }^{29}$ But the Katz Court rejected this result as incompatible with "the vital role that the public telephone has come to play in private communication." ${ }^{m 0}$ And the Court took the occasion the reject as obsolete the "trespass" theory underlying

${ }^{26} 389$ U.S. at 357 . The Court reiterated this point two years after Katz, when it overruled earlier decisions, including United States $v$. Rabinowitz, supra, that had upheld broad, warrantless searches following lawful arrests. See Chimel v. California, 395 U.S. 752, 762 (1969). The Court sharply limited warrantless searches following an arrest to the person of the arrestee and the area within his or her reach, see id. at 766 , and it rejected as unacceptably "subjective" the openended assessment of reasonableness undertaken in cases like Rabinowitz. Chimel, 395 U.S. at 764 . "Under such an unconfined analysis," the Court explained, "Fourth Amendment protection in this area would approach the evaporation point." Id. at 765; accord, United States v. United States District Court, 407 U.S. 297,315 \& n.16 (1972).

${ }^{27}$ Olmstead, 277 U.S. at 466.

${ }^{28} \mathrm{Katz}, 389$ U.S. at 348.

29 Indeed, there was not even a physical intrusion into the telephone booth, which of course was not the suspect's property in any event. The monitoring was carried out by tape recorders placed above the booths. See Katz v. United States, 369 F.2d 130, 131 (9th Cir. 1966), rev'd, 389 U.S. 347 (1967).

so Katz, 389 U.S. at 352. 
the Olmstead decision. ${ }^{31}$ Writing for the majority in Katz, Justice Stewart proclaimed, in words that were to become famous, "the Fourth Amendment protects people, not places." This meant, he explained, that "[w] hat a person knowingly exposes to the public, even in his own home or office, is not a subject of Fourth Amendment protection," but "what he seeks to preserve as private, even in an areas accessible to the public, may be constitutionally protected. ${ }^{\text {33 }}$ Eavesdropping on calls the defendant placed from a telephone booth constituted a "search and seizure" within the meaning of the Fourth Amendment, because it "violated the privacy upon which he justifiably relied when using the telephone booth. ${ }^{34}$

Katz parted from Olmstead not just on the narrow question whether electronic eavesdropping on telephone conversations is a search or seizure, and not just on the broader question whether a search or seizure requires a physical trespass or confiscation, but also, implicitly, on the still broader question of the proper role of history in interpreting the Fourth Amendment. Justice Stewart's opinion for the Court in Katz was strikingly forward-looking - or at least present-looking. It alluded repeatedly to the realities of modern life, but contained not a word about the background of the Fourth Amendment. Justice Black's dissent took up the subject in earnest, complaining that the Amendment "was aimed directly at the abhorred practice at breaking in, ransacking and searching homes and other buildings and seizing people's personal belongings without warrants issued by magistrates. ${ }^{.35}$ It was not aimed, Black argued, at eavesdropping. ${ }^{36}$ The majority did not even bother responding, so little did it appear to care

31 See id. at 352-53.

32 Id. at 351 .

ss Id.

34 Id. at 353; see also id. at 352 ("No less than an individual in a business office, in a friend's apartment, or in a taxicab, a person in a telephone booth may rely upon the protection of the Fourth Amendment. One who occupies it, shuts the door behind him, and pays the toll that permits him to play a call is surely entitled to assume that the words he utters into the mouthpiece will not be broadcast to the world.") (footnotes omitted).

${ }^{35}$ Id. at 367 (Black, J., dissenting).

${ }^{36}$ See id. at 366-67. 
about eighteenth-century history. In this respect Katz heralded a change in the Court's entire approach to the Fourth Amendment, not just in its thinking about what constitutes a search or seizure.

The modernizing, ahistorical approach that Katz took to the Fourth Amendment was extended six months later, in Terry $v$. Ohio, ${ }^{37}$ to the question of what makes a search or seizure "unreasonable." Terry concerned the legality of the widespread and controversial police tactic of stopping and frisking suspects without a warrant and without probable cause. ${ }^{38}$ The practice was particularly controversial when the Court decided Terry in 1968. Police harassment, much of it taking the form of "field interrogations," was widely thought to have contributed to the urban riots of $1967 .{ }^{39}$ Writing for the Court in Terry, Chief Justice Warren took explicit note, at some length, of the grievances provoked by investigatory stops and frisks, and also of the practicalities of modern policing and modern weaponry that seemed to require the practice. ${ }^{40}$ As in Katz, though, the Court in Terry had nothing to say about history. Like Katz, the opinion in Terry focused entirely on the present, not on the past.

And just as this focus led the Court in Katz to abandon the traditional definition of "searches and seizures," it led the Terry Court, after quoting Katz favorably, ${ }^{41}$ to break, at least in part, with the traditional test for the reasonableness of a search or seizure-the "per se" rule that searches and seizures

ง7 392 U.S. 1 (1968).

38 Terry, 392 U.S. at 4.

so In a report released three months before the Court decided Terry, the Kerner Commission placed police practices, including investigatory stops, at the top of the list of grievances leading to the riots. See REPORT OF THE NATIONAL ADVISORY COMMission ON CrvIL DisorDers 143-44, 302-04 (1968). The Terry Court itself quoted the earlier finding of the President's Commission on Law Enforcement and Administration of Justice that "[i]n many communities, field interrogations are a major source of friction between the police and minority groups." Terry, 392 U.S. at 14 n.11 (quoting PRESIDENT'S COMMISSION ON LAW Enforcement and ADministration of Justice, TASK FORCE REPORT: THE Police 183 (1967)).

to See Terry, 392 U.S. at 9-15, 23-24 \& n.21.

4 See id. at 9 ("We have recently held that the Fourth Amendment protects people, not places." $)$. 
are presumptively unreasonable unless carried out pursuant to warrant based on probable cause. ${ }^{42}$ Instead of struggling to fit the stop and frisk within one of the "few specifically established and well-delineated exceptions ${ }^{\text {n43 }}$ to that rule, or crafting a new, equally "well-delineated" exception, the Terry Court proceeded on the assumption that "the central inquiry under the Fourth Amendment" was "the reasonableness in all the circumstances of the particular governmental invasion. The requisite basis for the search or seizure therefore depended on the severity of the intrusion involved. In particular, a stop and frisk was not "unreasonable" simply because it was not authorized by a warrant, or because the police lacked the probable cause they would need for an arrest. ${ }^{45}$ Terry did not explicitly reject the Court's old approach to reasonableness, the approach that required all searches and seizures, subject to certain exceptions, to be authorized by a warrant based on probable cause. But it conspicuously failed to follow that approach, and set out a different, "sliding scale" approach in some detail. ${ }^{46}$

In neither Katz nor Terry did the Court's majority opinion do much to clarify the implications of its new, ahistorical approach to the Fourth Amendment. ${ }^{47}$ In both cases, Justice Harlan took up this task in a separate, concurring opinion. And in both cases he left a lasting mark on the law of search and seizure.

42 Id. at $21-22$.

4s Katz, 389 U.S. at 357.

4t Terry, 392 U.S. at 19 (emphasis added).

4s See id. at 26-27. A longstanding exception to the warrant requirement allowed warrantless, felony arrests based on probable cause. See United States v. Watson, 423 U.S. 411 (1976); Draper v. United States, 358 U.S. 307 (1959).

${ }^{48}$ For elaboration and praise of this aspect of Terry, see Christopher Slobogin, Let's Not Bury Terry: A Call for Rejuvenation of the Proportionality Principle, 72 ST. JoHN's L. REv. 1053 (1998). For a less positive assessment, see Tracey Maclin, Terry v. Ohio's Fourth Amendment Legacy: Black Men and Police Discretion, 72 ST. JoHN's L. REv. 1271 (1998).

${ }^{47}$ See, e.g., Edmund W. Kitch, Katz v. United States: The Limits of the Fourth Amendment, 1968 SUP. CT. REV. 133, 135 (noting that, in overturning "the property principle of Olmstead ... [t]he Court has been eager to abandon the limiting principle of the past, but inattentive to the more difficult task of articulating and applying a limiting principle for the future"). 
Harlan's contribution in Terry was relatively modest. His concurring opinion said nothing to elucidate the Court's general, "sliding scale" methodology or to explain how it should be reconciled with the more traditional approach to assessing the reasonableness of searches and seizures. He did clarify, though, the rules governing field interrogations. Warren's opinion for the Court in Terry held that the Fourth Amendment permits a police officer to frisk a suspect for weapons when the officer can "point to specific and articulable facts" reasonably supporting an inference that the officer "is dealing with an armed and dangerous individual. ${ }^{\text {48 }}$ But Warren said nothing about when the police may stop a suspect in the first place. ${ }^{49}$ Harlan answered this question by extending the Court's analysis. ${ }^{50}$ Just as a frisk is justified by reasonable articulable suspicion that a suspect is armed and dangerous, a brief stop for questioning may be based on reasonable articulable suspicion that a suspect is about to commit a crime. $^{51}$ The Court subsequently endorsed this understanding of Terry, ${ }^{52}$ and clarified that a stop can be based on reasonable articulable suspicion either of imminent criminal behavior or of a completed felony. ${ }^{53}$

Justice Harlan's contribution in Katz was more far-reaching than his contribution in Terry. He added to the Court's reasoning in Katz in two ways. First, Harlan explained that the Fourth Amendment protects "reasonable expectation[s] of privacy," which in turn require "first that a person have exhibited an actual (subjective) expectation of privacy and, second, that the expectation be one that society is prepared to recognize as 'reasonable." ${ }^{m 4}$ Second, notwithstanding the majority's rhetoric, Harlan opined that Fourth Amendment

4erry, 392 U.S. at $21,27$.

19 Indeed, he thought the case before the Court did not present that question. See id. at 19 n.16.

so Id. at 32-34 (Harlan, J., concurring).

51 See id.

${ }^{52}$ See, e.g., Adams v. Williams, 407 U.S. 143 (1972).

5s See United States v. Hensley, 469 U.S. 221 (1985).

${ }^{54} \mathrm{Katz}, 389$ U.S. at 360-61 (Harlan, J., concurring). 
protection typically attaches to particular locations. ${ }^{55}$ Of course, he agreed, "the Fourth Amendment protects people, not places." ${ }^{m 66}$ But "[t]he question ... is what protection it affords to those people," and "generally ... the answer to that question requires reference to a 'place." ${ }^{m 7}$ In Katz itself, Harlan reasoned, the Fourth Amendment applied only because "an enclosed telephone booth is an area where, like a home, ... occupants' expectations of freedom from intrusion are recognized as reasonable. ${ }^{p 58}$

Both of Justice Harlan's suggestions in Katz had lasting effects on the law of search and seizure-but more, perhaps, by posing questions than by answering them. The Court lost little time endorsing Harlan's suggestion in Katz that Fourth Amendment protection requires a "reasonable expectation of privacy." The Court embraced this gloss on Katz in Terry ${ }^{59}$ and has adhered to it since. But both the subjective and the objective prongs of the "reasonable expectation of privacy" test have raised difficulties. Conditioning Fourth Amendment protection on a suspect's "actual (subjective) expectation of privacy" has the odd consequence that people who suspect the government are spying on them may lose, for that very reason, much of their protection against what they fear. ${ }^{60}$ That it turn means the government could defeat expectations of privacy simply by declaring its intention to violate them: for example, by "announcing half-hourly on television ... that we were all being placed under comprehensive electronic surveillance. ${ }^{.61}$ To avoid these results, the Court has placed greater emphasis on the objective prong of Justice Harlan's test, the requirement "that the expectation be one that society is pre-

os Id.

B8 Id. at 361 .

67 Id.

58 Id. at $360-61$.

So See Terry, 392 U.S. at 9.

${ }^{6}$ See, e.g., John M. Burkoff, When Is a Search Not a "Search?" Fourth Amendment Doublethink, 15 TOLEDo L. REV. 515, 527 (1984); John M. Junker, The Structure of the Fourth Amendment: The Scope of the Protection, 79 J. CRIM. L. \& CRIMnOLOGY 1105, 1166 (1989).

61 Amsterdam, supra note 13 , at 384 . 
pared to recognize as "reasonable." ${ }^{m 2}$ But how are judges to tell whether society is in fact "prepared to recognize" an expectation as "reasonable"? The inquiry has proved distressingly indeterminate, and many observers, on and off the Court, have thought it circular: an expectation of privacy is reasonable if the Court is willing to protect it.

The Court has never explicitly adopted Justice Harlan's other gloss on Katz, the suggestion that Fourth Amendment protection, even if it does not require a trespass, still typically is limited to particular locations. ${ }^{63}$ Harlan's protestations notwithstanding, this reading of Katz appears hard to reconcile with the Court's grand proclamation, in Katz and many subsequent cases, that "the Fourth Amendment protects people, not places." Once one says, as Harlan did, that the protection the Amendment provides to people "generally requires reference to a 'place," the most famous words in Katz seem drained of most of their content. And even the central holding of Katz starts to look trivial if one ties it, as Harlan did, to an analogy between telephone booths and homes. As one commentator asked at the time, "Would the case have been different if the pay phone had not been surrounded by a booth?"164 The question has become more pressing as portable telephones have proliferated and pay telephones increasingly have lost their walls. But even without hindsight, it is easy to understand the Court's discomfort with Harlan's emphasis on the telephone booth as a physical location. ${ }^{65}$

Eee Hudson v. Palmer, 468 U.S. 517, 525 \& n.7 (1984); Smith v. Maryland, 442 U.S. 735, 740 n.5 (1979); Burkoff, supra note 60 , at 528-29.

6s Katz, 389 U.S. at $361-62$.

64 Kitch, supra note 47 , at 140 .

${ }_{65}$ In England several years ago, I bought a game called "You Be the Judge," which requires players to guess how courts decided actual cases, with names "changed to protect the innocent." One question concerns the case of "The Incriminating Phone Booths," which is described as involving the FBI's surreptitious taping of calls "Karl" placed from two public telephone booths. (The defendant in Katz was actually named Charles Katz. Oddly enough, though, there was a Carl Katz who appeared in Terry $v$. Ohio; he was one of two men arrested along with the petitioner. See State v. Terry, 214 N.E.2d 114, 123 (Ohio App. 1966), affd, 392 U.S. 1 (1968).) The answer explains that the Supreme Court ruled for Karl, "because a telephone booth is like a home in that it is a protected area where a person can reasonably expect privacy." Every year I read this to my criminal 
Still, while the Court keeps reiterating that "the Fourth Amendment protects people, not places, ${ }^{n 66}$ much of what the Court has said and done in search-and-seizure law has suggested Harlan was right to demur. In case after case-including, as we will see, in Kyllo-the Court has suggested that the Fourth Amendment offers heightened protection inside the home. ${ }^{67}$ In other places-automobiles, highways, fields, offices, even back yards-Fourth Amendment protection, as a practical matter, drops off dramatically or vanishes entirely. ${ }^{68}$

Years before Kyllo, the Court indicated that Fourth Amendment protection against advanced technologies of surveillance would depend, too, on where a suspect was-and, in

procedure students, and every year it gets a laugh-so contrary does it seem to the notion that "the Fourth Amendment protects people, not places."

${ }^{6}$ See Minnesota v. Carter, 525 U.S. 83, 88 (1998); Minnesota v. Olson, 495 U.S. 91, 96 n.5 (1990); Segura v. United States, 468 U.S. 796, 810 (1984); United States v. Mendenhall, 446 U.S. 544, 550 (1980); Smith v. Maryland, 442 U.S. 735, 739 (1979); United States v. Chadwick, 433 U.S. 1, 7, 9 (1977); United States v. Dionisio, 410 U.S. 1, 8 (1973); Desist v. United States, 394 U.S. 244, 246 (1969); Terry v. Ohio, 392 U.S. 1, 9 (1968).

${ }_{67}$ See, e.g., Wilson v. Layne, 526 U.S. 603 (1999); Karo v. United States, 468 U.S. 705, 714 (1984); Segura v. United States, 468 U.S. 796, 810 (1984); Payton v. New York, 445 U.S. 573 (1980); United States v. United States Dist. Court, 407 U.S. 297, 313 (1972); Thomas K. Clancy, What Does the Fourth Amendment Protect: Property, Privacy, or Security?, 33 WAKE FOREST L. REV. 307, 345-46 (1998).

${ }_{68}$ See, e.g., California v. Acevedo, 500 U.S. 565 (1991) (automobiles); Michigan Dep't of State Police v. Sitz, 496 U.S. 444 (1990) (highways); O'Connor v. Ortega, 480 U.S. 709 (1987) (offices); California v. Ciraolo, 476 U.S. 207 (1986) (backyards); Oliver v. United States, 466 U.S. 170 (1984) (fields). See generally Christopher Slobogin, Technologically-Assisted Physical Surveillance: The American Bar Association's Tentative Draft Standards, 10 HARV. J.L. \& TECH. 383, 390-91 (1997) (noting that in determining what kinds of physical surveillance constitute "searches" under Katz, "[t]he most important factor has been the nature of the place subjected to physical surveillance," and that "when the surveillance is of an area outside a residence or similarly private area, courts have often found the Fourth Amendment irrelevant"). Not only do homes receive especially strong protection under the Fourth Amendment, but certain places-notably automobiles and prison cells-receive especially weak protection. The Court has held that a "diminished expectation of privacy . . . surrounds the automobile," United States v. Chadwick, 433 U.S. 1, 12 (1977), and that "the Fourth Amendment proscription against unreasonable searches does not apply within the confines of the prison cell." Hudson v. Palmer, 468 U.S. 517, 526 (1984). 
particular, on whether he or she was at home. An electronic transmitter therefore effects no search or seizure when used to track a suspect on public highways, but implicates the Fourth Amendment the minute it sends signals from inside a home. ${ }^{69}$ What of the danger that transmitters might allow the government to engage in round-the-clock tracking of our every movement outside our homes, entirely unregulated by the Constitution? The Justices said they would cross that bridge when they came to it. For the time being, at least, "reality hardly suggest[ed] abuse."

The legacy of Katz is therefore conflicted. The Court has embraced Justice Harlan's suggestion that Fourth Amendment protection depends on a "reasonable expectation of privacy," but has never seemed certain what makes an expectation of privacy reasonable. And while repeatedly reaffirming that the "Fourth Amendment protects people, not places," the Court has simultaneously made clear that-just as Harlan opined-the extent of the protection "generally requires reference to a "place." The decision in Katz seemed to promise a Fourth Amendment that was less tied to specific locations, and therefore somehow more modern. The Justices keep renewing that promise, but they have never figured out how to make good on it.

Inevitably, their frustration led to doubts about the methodological subtext of Katz, the subtext it shared with that other pillar of modern Fourth Amendment law, Terry $v$. Ohio-the notion that Fourth Amendment jurisprudence should look forward rather than back. And in time those doubts led the Justices-some of them more quickly than others-to try to return search-and-seizure jurisprudence to its roots in eighteenth-century common law.

${ }^{69}$ See United States v. Karo, 468 U.S. 705 (1984); United States v. Knotts, 460 U.S. 276 (1983).

${ }^{70}$ Knotts, 460 U.S. at 283-84 (quoting Zurcher v. Stanford Daily, 436 U.S. 547, 566 (1978)). 


\section{B. Common $\operatorname{Law}^{71}$}

When Justice Scalia joined the Supreme Court in 1986, few people expected him to remake Fourth Amendment law. He had rarely written about search-and-seizure law, either as a law professor or as an appellate judge. And for his first several years on the Court, his Fourth Amendment opinions were, in fact, relatively conventional-albeit written with his characteristic flair and strongly colored by his preference for clear rules. Justice Scalia initially seemed content simply to apply Fourth Amendment law as he found it, retaining the modernizing legacy of Katz and Terry. ${ }^{72}$ Thus, for example, he wrote approvingly in one opinion that "[w] hile there are some absolutes in Fourth Amendment law, as soon as those have been left behind and the question comes down to whether a particular search has been 'reasonable,' the answer depends largely on the social necessity that prompts the search. ${ }^{\text {79 }}$

But Justice Scalia soon soured on Katz and Terry, and on the entire edifice of search-and-seizure doctrine they supported. He discovered, as others have, that modern Fourth Amendment law is rife with contradictions and indeterminacy. Over time he gravitated to what he thought was a remedy for those maladies: an alternative vision of search-and-seizure jurisprudence, anchored securely in eighteenth-century common law.

He began by suggesting that "the Fourth Amendment's prohibition of 'unreasonable seizures,' insofar as it applies to seizure of the person, preserves for our citizens the traditional protections against unlawful arrest afforded by the common

71 Much of this section is drawn from a more detailed discussion in Sklansky, supra note 12, at 1745-70, 1774-1807.

${ }^{72}$ See Illinois v. Rodriguez, 497 U.S. 177 (1990); Nat'l Treasury Employees Union v. Von Raab, 489 U.S. 656, 681 (1989) (Scalia, J., dissenting); Brower v. County of Inyo, 489 U.S. 593 (1989); Arizona v. Hicks, 480 U.S. 321 (1987); Griffin v. Wisconsin, 483 U.S. 868 (1987); O'Connor v. Ortega, 480 U.S. 709, 730 (1987) (Scalia, J., concurring).

73 Nat'l Treasury Employees Union, 489 U.S. at 686-87 (Scalia, J., dissenting). 
law." Soon thereafter he broadened his claim: "the 'reasonableness' requirement of the Fourth Amendment," he argued, "affords the protection that the common law afforded." This understanding of the Amendment would give search-and-seizure law clarity and stability, and it would allow the Amendment to do what any constitutional provision should do: put certain matters "beyond time, place, and judicial predilection." 76 The whole point of the Fourth Amendment, Scalia contended, was "to preserve that degree of respect for the privacy of persons and the inviolability of their property" that existed at common law. ${ }^{77}$ Applying the Amendment might occasionally require the Court to balance law enforcement interests against privacy concerns, but only when "there was no clear practice, either approving or disapproving the type of search at issue, at the time the constitutional provision was enacted."78 For all other questions, "the 'balance' has already been struck."79

This view of the Fourth Amendment-a view I have elsewhere termed "the new Fourth Amendment originalism" -was obviously in considerable tension with the modernizing, ahistorical approach of Katz and Terry. Indeed, it was in large part a reaction against Katz and Terry and what they had wrought. (In part it was also a reaction against an older, less self-consciously modernizing aspect of the Court's Fourth Amendment jurisprudence, the notion that a search or seizure generally is "unreasonable" within the meaning of the Amendment unless it is authorized by a warrant. $)^{81}$ Scalia derided

74 County of Riverside v. McLaughlin, 500 U.S. 44, 60 (1991) (Scalia, J., dissenting); see also California v. Hodari D., 499 U.S. 621, 624 (1991) (consulting common-law decisions to determine the meaning of "seizure" in the Fourth Amendment).

75 California v. Acevedo, 500 U.S. 565, 583 (1991) (Scalia, J., concurring).

${ }^{76}$ McLaughlin, 500 U.S. at 66.

" Minnesota v. Dickerson, 508 U.S. 366, 380 (1993) (Scalia, J., concurring).

${ }_{78}$ Vernonia Sch. Dist. 47J v. Acton, 515 U.S. 646, 652-53 (1995).

${ }^{79}$ McLaughlin, 500 U.S. at 60 (Scalia, J., dissenting).

Bo Sklansky, supra note 12 , at 1744 . Kathryn Urbonya has taken note of the same doctrinal development. See Kathryn R. Urbonya, Determining Reasonableness Under the Fourth Amendment: Physical Force to Control and Punish Students, 10 CORNELl J.L. \& PUB. Pol'Y 397, 411-12 (2001).

${ }^{81}$ See Acevedo, 500 U.S. at 583 (Scalia, J., concurring); Urbonya, supra note 
Terry as an application of "the original-meaning-is-irrelevant, good-policy-is-constitutional-law school of jurisprudence. ${ }^{782}$ And he complained that the chief legacy of Katz-Justice Harlan's "reasonable expectation of privacy" test-lacked any "plausible foundation in the text of the Fourth Amendment," and was "self-indulgent" to boot. ${ }^{83}$ In practice, Scalia charged, "reasonable expectations of privacy" were simply "those expectations of privacy that this Court considers reasonable"-no more and no less. ${ }^{84}$

When he first voiced these sentiments, Justice Scalia spoke only for himself. But he soon found a convert in Justice Thomas. In Wilson v. Arkansas, his first opinion for the Court in a Fourth Amendment case, Thomas suggested that in determining the scope of the Amendment "we have looked to the traditional protections against unreasonable searches and seizures afforded by the common law at the time of the framing. ${ }^{855}$ The case in question concerned the constitutional status of the traditional rule requiring law enforcement officers to knock and to announce their presence before searching a home. ${ }^{86}$ To reach the unremarkable conclusion that, depending on all the circumstances, a violation of this rule might make a search "unreasonable" under the Fourth Amendment, Justice Thomas reviewed common-law decisions dating from the early seventeenth century up through the $1800 \mathrm{~s}^{87} \mathrm{He}$ ignored Katz and Terry entirely, and-significantly-he spoke for a unanimous Court. No Justice objected to the importance Thomas gave common law in assessing the constitutionality of searches and seizures.

What Justice Thomas suggested for the Court, Justice Scalia finally announced explicitly for the Court four years later. Writing for the majority in Wyoming $v$. Houghton, ${ }^{88}$

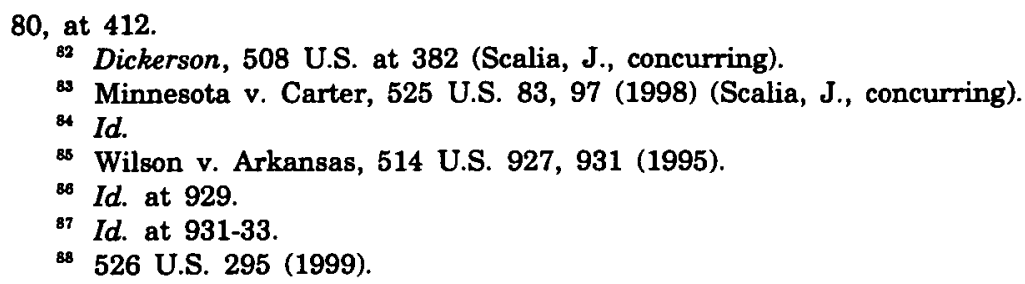


Justice Scalia explained that in applying the Fourth Amendment the Court asks first whether the challenged conduct "was regarded as an unlawful search or seizure under the common law when the Amendment was framed." ${ }^{n 9}$ Only if "that inquiry yields no answer" will the Court assess the search or seizure "under traditional standards of reasonableness," balancing the intrusion on privacy against "the promotion of legitimate government interests."

This was a good deal more emphatic than Justice Thomas's earlier suggestion for the Court that interpretation of the Fourth Amendment "may be guided" by eighteenth-century understandings, ${ }^{91}$ and it drew an objection from Justice Stevens. "To my knowledge," he wrote in dissent, "we have never restricted ourselves to a two-step Fourth Amendment approach wherein the privacy and governmental interests at stake must be considered only if 18 th-century common law 'yields no answer."'m2 But only Justice Souter and Justice Ginsburg joined his opinion. ${ }^{93}$

The new Fourth Amendment originalism was not wholly novel, but it differed in important ways from its antecedents. Justice Story had called the Fourth Amendment "little more than the affirmance of a great constitutional doctrine of the common law," but the "great constitutional doctrine" he had in mind was probably not a set of specific rules but rather the general tradition of disallowing unreasonable searches and seizures. ${ }^{95}$ Chief Justice Taft had written for the Court that

B9 Houghton, 526 U.S. at 299.

0 Id. at 299-300.

91 Wilson, 514 U.S. at 931.

Houghton, 526 U.S. at 311 n.3 (Stevens, J., dissenting).

* Justice Breyer joined the Court's opinion "with the understanding that history is meant to inform, but not automatically to determine, the answer to a Fourth Amendment question." Id. at 307 (Breyer, J., concurring).

* 2 Joseph Story, Commentaries on THE CONSTITUTION OF THE UNITED STATES \& 1902, at 679 (3d ed. 1958).

So See Sklansky, supra note 12, at 1786-87. The same may be said of the occasional suggestions by early-nineteenth-century courts that the Fourth Amendment and its state analogs were "nothing more than an affirmance of the common law." Wakely v. Hart, 6 Binn. 316, 319 (Pa. 1814). And the same may be said of then-Judge Cardozo's much later statement that New York's statutory version of the Fourth Amendment provided "immunity ... not from all search and seizure, 
"[t]he Fourth Amendment is to be construed in light of what was deemed an unreasonable search and seizure when it was adopted," but he had added that it should also be construed "in a manner which will conserve public interests as well as the interests and rights of individual citizens. ${ }^{196}$ Before Katz, history was a dominant theme of search-and-seizure jurisprudence generally-but usually history was consulted to shed light on the central concerns of the Fourth Amendment, not to locate its precise commands. ${ }^{97}$ And after Katz, the Supreme Court still occasionally consulted eighteenth-century common law as a guide to what searches and seizures were "unreasonable" within the meaning of the Fourth Amendment-but only as a very rough guide, "relevant" but certainly not "dispositive." 98

but from search and seizure unreasonable in light of common-law traditions." People v. Chiagles, 142 N.E. 583, 583 (N.Y. 1923). Justice Scalia cited Chiagles in his concurring opinion in California v. Acevedo. See 500 U.S. at 583. For a contrary reading of Story's remark-and, by implication, of Cardozo's-see Davies, supra note 23, at 618 n.190.

${ }^{96}$ Carroll v. United States, 267 U.S. 132, 149 (1925). In Minnesota v. Dickerson, Justice Scalia quoted the first half of Taft's direction but not the second half. 508 U.S. at 379-80 (Scalia, J., concurring).

97 Justice Frankfurter, who "more than any of the other Justices sought the fourth amendment's meaning in its history," Amsterdam, supra note 13, at 397, treated the specific grievances giving rise to the Fourth Amendment as what Jed Rubenfeld has called "paradigm cases," and Frankfurter used them as Rubenfeld recommends: "to illuminate ... what particular abuses most provoked those who framed and ratified the provision ... and what it was about those abuses that most provoked them." Jed Rubenfeld, Reading the Constitution as Spoken, 104 YALE L.J. 1119, 1170 (1995); see also Amsterdam, supra note 13, at 396. He shared this method with the two most famous uses of history in Fourth Amendment jurisprudence: Justice Bradley's celebrated opinion for the Court in Boyd $v$. United States, 116 U.S. 616 (1886), and the equally celebrated dissent by Justice Brandeis in Olmstead v. United States, 277 U.S. 438 (1928). On Boyd, see, for example, JacoB W. LANDYNSKI, SEARCH aNd SEIZURE aND THE SUPREME CourT 60-61 (1966). Regarding the Brandeis dissent in Olmstead, see, for example, James BoYd White, Justice as Translation: AN EsSay in Cultural and LEgAL CRITICISM 149-57 (1990); Lawrence Lessig, Fidelity in Translation, 71 TEx. L. REV. 1165, 1239-40 (1993).

${ }_{98}$ Payton v. New York, 445 U.S. 573, 591 (1980); see also Tennessee v. Garner, 471 U.S. 1, $12-14$ (1985); Steagald v. United States, 451 U.S. 204, 217 n.10 (1981); United States v. Watson, 423 U.S. 411, 415-23 (1976); Gerstein v. Pugh, 420 U.S. 103, 114 (1975). The Court stressed in Payton that "[t]here are important differences between the common-law rules relating to searches and seizures 
Justice Scalia's new Fourth Amendment originalism, embraced by the Court in Wyoming $v$. Houghton, really was something new. History had played a role in Fourth Amendment law before, but never in quite this way. Never before had the Court treated the status of searches and seizures under eighteenth-century common law as the chief measure of their constitutionality today.

And for good reason. The Fourth Amendment does not forbid "searches and seizures illegal at common law"; it forbids "unreasonable searches and seizures." This language almost certainly was understood when the Fourth Amendment was framed and adopted the same way most people would understand it today: not as code for "searches illegal at common law," but as an open-ended reference to searches that are in some way inappropriate or excessive. ${ }^{99}$ Nor does the available evidence suggest that anyone intended the Fourth Amendment to bar only searches and seizures proscribed by common law. ${ }^{100}$ Nor, finally, is defining "reasonableness" by reference to eighteenth-century common law likely to do much to make Fourth Amendment law more stable or more coherent. Eighteenth-century common law was not the elaborate edifice of nationwide precedents that would later be codified in the Restatements; it was an incomplete hodgepodge of maxims, court rulings, and statutes that varied from place to place and changed over time. ${ }^{101}$ To a great extent, therefore, an-

and those that have evolved through the process of interpreting the Fourth Amendment in light of contemporary norms and conditions," and that "this Court has not simply frozen into constitutional law those law enforcement practices that existed at the time of the Fourth Amendment's passage." Payton, 445 U.S. at 591 n.33; see also Garner, 471 U.S. at 11-13 (quoting the latter statement with approval); Steagald, 451 U.S. at 217 n.10 (same).

See Amsterdam, supra note 13, at 399; Sklansky, supra note 12, at 177684; Carol S. Steiker, Second Thoughts About First Principles, 107 HARV. L. REV. 820, 824 (1994). For a dissenting view, see Davies, supra note 23, at 686-93. For a response to Davies, see Sklansky, supra note 12 , at 1780 n.250.

100 See Sklansky, supra note 12 , at 1784-93.

102 See Perry MILler, THE LIFE of tHe Mind In AMERICa: From the RevoluTION TO THE CIVIL WAR 121 (1965); Cloud, supra note 23, at 1716-17; Harry W. Jones, The Common Law in the United States: English Themes and American Variations, in Political SeParation aND Legal ContinUtTy 91, 98 (Harry W. Jones ed., 1976); Sklansky, supra note 12, at 1795-1807; Charles W. Wolfram, The 
choring the Fourth Amendment in eighteenth-century common law is anchoring it in sand. ${ }^{102}$ Further indeterminacy is added by the Court's caveat in Houghton that when common law "yields no answer," we are back to the present, balancing law enforcement interests against privacy concerns. ${ }^{103}$

Of course the new Fourth Amendment originalism does offer some guidance, if nothing else by suggesting that the most important questions to be raised about searches and seizures are the ones raised by eighteenth-century common law. But that may not be guidance worth following: the search-and-seizure law of the 1700 s was entirely unconcerned with certain questions that it may be important for modern Fourth Amendment doctrine to address. One such set of issues are those involving race, class and gender equity-issues ignored by eighteenth-century rules of search and seizure, which systematically codified class privilege. ${ }^{104}$ Another set concerns what government does with the information that it collects through searches and seizures-an issue in which eighteenth-century common law showed little interest, but which computerized monitoring and data management have made much more pressing. ${ }^{105}$

Constitutional History of the Seventh Amendment, 57 MINN. L. REv. 639, 665, 734 (1973).

${ }^{102}$ Cf. Urbonya, supra note 80 , at 412 (arguing that "one can characterize common-law practices in a variety of ways," and therefore that "[d]rawing upon the common law as a primary basis for Fourth Amendment reaonableness analysis is no easy task").

${ }^{103}$ See Houghton, 526 U.S. at 299-300.

${ }^{104}$ See Sklansky, supra note 12, at 408-14. Current Fourth Amendment doctrine does not in fact place much emphasis on issues of equality. The Court has said that constitutional challenges to discrimination should be raised under "the Equal Protection Clause, not the Fourth Amendment." Whren v. United States, 517 U.S. 806, 813 (1996). Still, many people today believe that the "reasonableness" of a search or seizure should depend in part on considerations of race, class and gender equity. See, e.g., Amar, supra note 25, at 808-09; Amsterdam, supra note 13, at 401, 416-17; Devon W. Carbado, (E)racing the Fourth Amendment, 100 MicH. L. REV. 946 (2002); Tracey Maclin, Race and the Fourth Amendment, 51 VAND. L. REV. 333 (1998); Steiker, supra note 99, at 830-44; William J. Stuntz, The Distribution of Fourth Amendment Privacy, 67 Geo. WASH. L. REv. 1265, 1265-67 (1999).

${ }^{106}$ See Harold J. Krent, Of Diaries and Data Banks: Use Restrictions Under the Fourth Amendment, 74 TEx. L. REv. 49 (1995); Slobogin, supra note 68, at 
Whatever its shortcomings, though, the approach to the Fourth Amendment championed by Justice Scalia throughout the 1990s and finally endorsed by the Court in Houghton represented a dramatic shift away from the modernizing, ahistorical jurisprudence of Katz and Terry. If Katz and Terry focused Fourth Amendment law more single-mindedly on present-day problems than it ever had been focused before, the new Fourth Amendment originalism veered just as far in the other direction, fixing the gaze of search-and-seizure firmly on the past. Not for nothing had Akhil Amar described Scalia's new method, before the Court adopted it, as a "frozen in amber' approach to Fourth Amendment reasonableness." 106

Perhaps because the new Fourth Amendment originalism was so radical, the Supreme Court has seemed unsure how fully to embrace it. Shortly after Houghton seven members of the Court reaffirmed, in an opinion authored by Justice Thomas, that "[i]n deciding whether a challenged governmental action violates the [Fourth] Amendment, we have taken care to inquire whether the action was regarded as an unlawful search and seizure when the Amendment was framed."107 One week later, when the Court held a home arrest "unreasonable" under the Fourth Amendment because the police had brought along reporters, Chief Justice Rehnquist began his analysis for the Court with Blackstone's remarks about the sanctity of the home, and with the 1604 decision in Semayne's Case, the source of the maxim that "the house of every one is to him as his castle and fortress ${ }^{\text {108 }}$ - thereby suggesting that even when no pre-enactment authorities were remotely on point, the common law remained the prime measure of Fourth Amendment reasonableness. ${ }^{109}$ In other search-and-seizure

402; Jeffrey Rosen, Silicon Valley's Spy Game, N.Y. Times, Apr. 14, 2002, at $\$ 6$ (Magazine), at 46; infra note 258 and accompanying text.

${ }^{106}$ Amar, supra note 25, at 818 \& n.230.

10f Florida v. White, 526 U.S. 559, 563 (1999). Justice Stevens dissented, joined only by Justice Ginsburg. See id. at 567 (Stevens, J., dissenting).

${ }_{106}$ Wilson v. Layne, 526 U.S. 603, 609-10 (1999) (quoting Semayne's Case, 77 Eng. Rep. 194 (K.B. 1604) and 4 WILLIAM Blackstone, CommentarIes *223).

${ }^{109}$ Id. Chief Justice Rehnquist spoke in this portion of his opinion for a unanimous Court. Justice Stevens dissented only from a later portion of the opinion, which found the officers entitled to qualified immunity because the constitutional 
cases after Houghton, though, the Court ignored common law and instead turned for guidance to Katz, Terry, and their progeny. ${ }^{110}$ And in one case five members of the Court, led by Justice Souter, reaffirmed that " $[i] n$ reading the Amendment, we are guided by the traditional protections against unreasonable searches and seizures afforded by the common law at the time of the framing," but also renewed the suggestion that this history is "relevant" but not "dispositive." 111

It was in this context that the Court decided Kyllo $v$. United States.

\section{The CONTENT OF KYLLO}

The Supreme Court's ruling in Kyllo $v$. United States addressed the constitutionality of an investigative step taken almost a decade earlier in the coastal town of Florence, Oregon. ${ }^{112}$ A task force of federal and state narcotics officers suspected Danny Lee Kyllo was growing marijuana in his home,

prohibition of media "ride-alongs" had not been "clearly established." Wilson, 526 U.S. at 616-18. And by this point even Justice Stevens seemed to fight on the terrain of the new Fourth Amendment originalism: he argued that to find media ride-alongs constitutional would require "reevaluation" of "the rule in Semayne's Case." Id. at 622 (Stevens, J., dissenting). Like much of the bistoriography of the new Fourth Amendment originalism, this was something of a stretch. The actual decision in Seymane's Case declared the home a "castle and fortress" only against entries to vindicate private interests, not in cases in which the King was a party. See Semayne's Case, 77 Eng. Rep. at 195-96. This limitation was apparently well known at the time of the adoption of the Fourth Amendment, and it elsewhere has been noted by the Court. See Payton v. New York, 445 U.S. 573, 592 (1980); id. at 605 (White, J., dissenting); Sklansky, supra note 12, at 1761 n.143.

${ }^{110}$ See Illinois v. McArthur, 531 U.S. 326 (2001) (finding that temporary eviction of suspect from his home pending issuance of search warrant was not an "unreasonable" seizure); City of Indianapolis v. Edmond, 531 U.S. 32 (2000) (striking down highway checkpoints aimed at curtailing drug trafficking); Bond v. United States, 529 U.S. 334 (2000) (concluding that squeezing the baggage of bus passengers to feel for contraband is a "search"); Florida v. J.L., 529 U.S. 266 (2000) (disapproving a stop and frisk based solely on an anonymous tip that the suspect was carrying a gun); Illinois v. Wardlow, 528 U.S. 119 (2000) (approving an investigatory stop based on the suspect's flight from police in an area known for drug trafficking).

11 Atwater v. City of Lago Vista, 532 U.S. 318, 326, 1543 (2001) (quoting Wilson v. Arkansas, 514 U.S. 927, 931 (1995), and Payton v. New York, 445 U.S. 573, 591 (1980)).

12533 U.S. 27, 29-30 (2001). 
which was part of a triplex. ${ }^{113}$ To confirm their suspicions and to generate sufficient evidence to get a search warrant, they looked for indications that Kyllo was using the high-intensity lights typically needed for indoor cultivation of marijuana. ${ }^{114}$ The agents checked the records of the local power company and concluded that Kyllo used an usually large amount of electricity. ${ }^{115}$ Then they drove out to the triplex at night and aimed a "thermal imager" at it from the surrounding streets. ${ }^{116}$

A thermal imager is essentially a video camera that records infrared radiation-i.e., heat-instead of visible light. ${ }^{117}$ The brochure for the particular device pointed at Kyllo's home, the Agema Thermovision 210, boasted that the device was "sensitive to differences as small as $0.9 \mathrm{~F}$ " and could "detect and delineate objects or persons in complete darkness, or under natural cover, as far away as 1500 feet." ${ }^{118}$ More to the point for the officers investigating Kyllo, it could measure the heat radiated out from the wall of a building. When the agents aimed the Thermovision 210 at the triplex in Florence, Oregon, it showed that one wall of Kyllo's residence, and the roof over his garage, were warmer than the rest of the home, and much warmer than the walls and roofs of the other two units in the triplex. ${ }^{119}$

Armed with these results and the records of Kyllo's electricity usage, the officers secured a federal warrant to search

11 Kyllo, 533 U.S. at 29.

114 Id.

11 Id.

118 Id. at $29-30$.

${ }^{17}$ See, e.g., Michael L. Huskins, Comment, Marijuana Hot Spots: Infrared Imaging and the Fourth Amendment, 63 U. CHI. L. REv. 655, 658-64 (1996). For examples of pictures produced by thermal imagers, see, for example, http://www.leta.org/images.htm (last visited June 26, 2002) (maintained by Law Enforcement Thermographers' Association).

118 The brochure is quoted in United States v. Kyllo, 140 F.3d 1249, 1254 (9th Cir. 1998), superceded, 190 F.3d 1041 (9th Cir. 1999), rev'd, 533 U.S. 27 (2001).

119 Kyllo, 533 U.S. at 30 . Images from the videotape are reproduced as an appendix to the dissent by Justice Stevens. See id. at 51. For higher-quality copies, see http://supct.law.cornell.edu/supct/pdf/99-8508P.ZD (last visited June 26, 2002). 
Kyllo's home. ${ }^{120}$ Inside, they found more than a hundred marijuana plants. ${ }^{21}$ Kyllo was indicted for growing marijuana, and he moved to suppress the evidence seized in his home. ${ }^{122}$ Thus began a long, back-and-forth legal battle over the legacy of Katz $v$. United States-a battle fought out in eight published opinions over the course of nine years.

\section{A. Kyllo in the Lower Courts}

Kyllo argued that pointing the thermal imager at his home was a "search" within the meaning of the Fourth Amendment, and consequently that it was illegal without a warrant, and that the warrant ultimately issued for a search of his home was tainted by the earlier, warrantless monitoring. ${ }^{129}$ The district court rejected the initial premise, that the use of the thermal imager was a "search." ${ }^{p 24}$ In a terse paragraph, the district court suggested three reasons for its result: (1) "waste heat" from a home is like garbage left for collection, which the Supreme Court has held is unprotected by any reasonable expectation of privacy; ${ }^{125}$ (2) there was no "intrusion" into Kyllo's residence; and (3) the thermal imager did not disclose any "intimate details" from within the home. ${ }^{126}$

130 Kyllo, 533 U.S. at 30.

121 Id.

${ }^{122}$ Id.

${ }^{123}$ Kyllo, 190 F.3d 1041, 1045 (9th Cir. 1999), rev'd, 533 U.S. 27 (2001). He also angued that the warrant ultimately issued for a search of his home was illegal because the agents misled the magistrate regarding matters others than the thermal imaging, and that the involvement of National Guard personnel in the task force investigating him violated the Posse Comitatus Act. These arguments were rejected in stages by the district court and the Ninth Circuit, and Kyllo did not pursue them before the Supreme Court. See United States v. Kyllo, 190 F.3d 1041, 1047 (9th Cir. 1999), rev'd on other grounds, 533 U.S. 27 (2001); United States v. Kyllo, 37 F.3d 526, 528-29 (9th Cir. 1994); United States v. Kyllo, 809 F. Supp. 787, 792-93 (D. Or. 1993), rev'd on other grounds, 37 F.3d 526 (9th Cir. 1994).

${ }^{124}$ Kyllo, 809 F. Supp. at 791-92.

${ }^{25}$ See California v. Greenwood, 486 U.S. 35 (1988).

${ }^{128}$ Kyllo, 809 F. Supp. at 792, rev'd, 37 F.3d 526 (9th Cir. 1994). For the point about "waste heat," the district court cited United States v. Penny-Feeney, 773 F. Supp. 220 (D. Haw. 1991), which held that a thermal imager violated no actual, subjective expectation of privacy where the suspects took no steps to prevent 
The Ninth Circuit seemed to find the third argument most important. Writing for a unanimous panel, Judge Norris took note of the Supreme Court's remarks in Dow Chemical Co. $v$. United States, ${ }^{127}$ a case upholding high-magnification aerial surveillance of an industrial facility. ${ }^{128}$ The Justices there had suggested that "surveillance of private property by using highly sophisticated surveillance equipment not generally available to the public . . . might be constitutionally proscribed absent a warrant," but they had concluded that the photographs in the case before them were "not so revealing of intimate details as to raise constitutional concerns. ${ }^{\text {"129 }}$ Because the district court in Kyllo had held no hearings on the capabilities of the Thermovision 210, the court of appeals remanded for an inquiry into what details the thermal imager actually could reveal. ${ }^{130}$

After dutifully hearing evidence on this question, the district court found that the device displayed only "a crude visual image of the ... house" and could not "show any people or activities within the walls of the structure."131 The district court therefore reiterated its conclusion that "[n]o intimate details of the home were observed." The trial judge also took the opportunity to remind the Ninth Circuit that the Thermovision 210 was "a non-intrusive device which emits no rays or beams," and that it detects only "surface waste heat." 132

These findings might have satisfied the panel that heard the first appeal in $K y l l o$, but the second appeal went to a different panel. The new panel was unconvinced by the district court's reasoning. Writing for the majority, Judge Merhige

\footnotetext{
"heat waste" or "abandoned heat" heat from escaping from their residence. PennyFeeney, 773 F. Supp. at 225-26. The argument was stronger in Penny-Feeney than in Kyllo, because the defendants in the earlier case had "used exhaust fans and various other means to vent the heat outside of the premises." Id. at 225.

127476 U.S. 227 (1986).

${ }^{128}$ Kyllo, 37 F.3d at 531 n.3.

129 Dow Chem. Co., 476 U.S. at 238.

13037 F.3d at 531.

191 U.S. v. Kyllo, No. CR. 92-51-FR, 1996 WL 125594, at *2 (D. Or. Mar. 15, 1996).

1 Is.
} 
distinguished Dow Chemical on the ground that the search in this case was of a home. ${ }^{133}$ Crude as it was, the Thermovision 210 might reveal household activities such as use of showers, bathtubs, or household appliances, and even "routine and trivial activities conducted in our homes" were "sufficiently "intimate" to merit Fourth Amendment protection. ${ }^{134}$ Moreover, Judge Merhige warned that "technology improves at a rapid pace, and much more powerful and sophisticated thermal imagers are being developed which are increasingly able to reveal the intimacies that we have heretofore trusted take place in private. ${ }^{\boldsymbol{1 3 5}}$

Judge Merhige also rejected 'the heat waste' analogy." 136 He noted that several other circuits had drawn this analogy in concluding that thermal imaging intrudes on no actual, subjective expectation of privacy. ${ }^{137}$ But he reasoned that the relevant question was not whether Kyllo expected privacy in the heat radiating from his house, but rather whether he expected privacy in what the thermal imager used that heat to reveal-namely, his activities inside the house. ${ }^{138}$ As to those activities, Merhige concluded, Kyllo clearly had an actual, subjective expectation of privacy. ${ }^{139}$ And given the special protection the Fourth Amendment provides to the home, Merhige thought Kyllo's expectation was objectively reason-

133 United States v. Kyllo, 140 F.3d 1249, 1255 (9th Cir. 1998), superceded, 190 F.3d 1041 (9th Cir. 1999), rev'd, 533 U.S. 27 (2001).

134 Id.

135 Id.

136 Id. at 1253 .

187 Id., citing United States v. Robinson, 62 F.3d 1325, 1328-29 (11th Cir. 1995); United States v. Myers, 46 F.3d 668, 669-70 (7th Cir. 1995); United States v. Pinson, 24 F.3d 1056, 1058 (8th Cir. 1994). By contrast, when holding that garbage left for collection is unprotected by the Fourth Amendment, the Supreme Court had reached no conclusion regarding the existence of an actual, subjective expectation of privacy, and instead had reasoned simply that such an expectation would not be "objectively reasonable." Greenwood, 486 U.S. at 39 (noting "[i]t may well be that respondents did not expect that the contents of their garbage bags would become known to the police or other members of the public").

${ }_{138}$ Kyllo, 140 F.3d at 1253 . On this point Judge Merhige followed United States v. Cusumano, 67 F.3d 1497, 1502 (10th Cir. 1995), vacated on other grounds, 83 F.3d 1247 (10th Cir. 1996).

${ }^{139}$ Kyllo, $140 \mathrm{~F} .3 \mathrm{~d}$ at $1253-54$. 
able. ${ }^{140}$

In a short dissent, Judge Hawkins raised the remaining argument the district court had advanced: the "non-intrusive" nature of thermal imaging. ${ }^{141}$ A search, Judge Hawkins reasoned, requires "an intrusion; a non-consensual invasion of protected space." 142 Because the thermal imager "intruded into nothing" and simply "measured the heat emanating from and on the outside of a house," it was not covered by the Fourth Amendment. ${ }^{143}$

He had an opportunity to elaborate the following year, after the panel agreed to rehear the case and Judge Merhige, a district judge who had sat by designation, was replaced by Judge Brunetti. Judge Brunetti came to share Judge Hawkins's view of the case, and so Judge Hawkins found himself writing for the majority. He noted again that thermal imaging is "non-intrusive"-indeed, he analogized the monitoring of heat radiating from a home to the sniffing of odors by a dog trained to detect narcotics. ${ }^{144}$ But Judge Hawkins devoted the bulk of the panel's new opinion to advancing precisely the two arguments Judge Merhige had rejected. First, Kyllo had no actual, subjective expectation of privacy, because he took no steps to stop heat from radiating out from his home. ${ }^{145}$ Second, the thermal imager "did not expose any intimate details of Kyllo's life," but simply "indicated amorphous 'hot spots' on the roof and exterior wall."146 And unlike Judge Merhige, Judge Hawkins thought the future potential of thermal imaging irrelevant: "[w]hile this technology may, in other circumstances, be or become advanced to the point that its use

140 Id. at 1255 .

141 Id.

142 Id.

14s Id.

14 United States v. Kyllo, 190 F.3d 1041, 1046 (9th Cir. 1999), rev'd, 533 U.S. 27 (2001). The Supreme Court had held in United States v. Place, 462 U.S. 696 (1983), that sniffing of luggage by a dog trained to detect narcotics is not a search, but the Court there emphasized not the non-invasive nature of the sniffing, but the fact that "the sniff discloses only the presence or absence of narcotics, a contraband item." Place, 426 U.S. at 707.

145 Kyllo, 190 F.3d at 1046.

146 Id. 
will step over the edge... into impermissible warrantless search, we find no violation of the Fourth Amendment on these facts." 147

Judge Noonan, who had joined Judge Merhige's earlier opinion for the panel, filed a dissent, which reiterated and amplified Judge Merhige's arguments. ${ }^{148}$ Like Judge Merhige, Judge Noonan stressed that the surveillance here was of a home. ${ }^{149}$ And like Judge Merhige, he rejected the analogy to "waste heat," and argued that Kyllo's critical expectations were those regarding "the privacy of the interior of his home. ${ }^{150}$ Indeed, Judge Noonan argued, it was particularly senseless to focus on Kyllo's expectations regarding the heat radiating from his home, because he almost certainly had no such expectations one way or the other. ${ }^{151}$ It was also senseless, Judge Noonan thought, to focus on the absence of any physical intrusion, because Katz made clear that "a forbidden search can occur even when no trespass is involved." ${ }^{152}$ And he ridiculed the idea that the crude nature of the Thermovision 210 rendered its warrantless use constitutional: "It is as though if your home was searched by a blind policeman you would have suffered no constitutional deprivation. ... The machine as blind or blundering constable does not pass the criteria of the Fourth Amendment."153 Thermal imaging raised fears for Judge Noonan of "Orwellian surveillance," and he agreed with Judge Merhige that even "the present, not potential" capabilities of thermal imaging violated reasonable expectations of privacy when the device was used

147 Id. (emphasis added).

148 Id. at 1047-49 (Noonan, J., dissenting).

149 Id. at 1048,1049 ("I start with the proposition that '[t]he sanctity of the home is not be disputed.' . . . Society has determined that it is reasonable for the home to be a citadel safe from warrantless inspection") (quoting Segura v. United States, 468 U.S. 796, 810 (1984)) (alteration in original).

150 Id. at 1049.

151 Id.

152 Id. at 1048 .

153 Id. at 1050, 1051. Indeed, Judge Noonan pointed out the majority's argument to the contrary was the opposite of the argument that the Supreme Court had found justified warrantless dog sniffs- "they revealed only contraband and nothing else." Id. at 1051. 
to detect activities within a home. ${ }^{154}$

Among the most interesting aspects of the various lower court opinions in Kyllo was their complicated relationship to the legacy of Katz. Each side of the debate that played itself out in these opinions rejected a different part of that legacy. By focusing repeatedly on the "non-intrusive" nature of thermal imaging-the fact that a thermal imager "emits no rays or beams" and just monitors "surface waste heat" - the district court and later Judge Hawkins seemed to disregard one of the central holdings of Katz, the Supreme Court's rejection of the notion that a search requires some kind of a trespass or physical invasion. ${ }^{155}$ On the other hand, the stress that Judge Merhige and Judge Noonan placed on the special sanctity of the home seemed in tension with the most famous part of Katz, the notion that "the Fourth Amendment protects people, not places." While each side in the lower court debates in Kyllo thus rejected part of what Katz seemed to stand for, both sides also were quite strikingly faithful to a more fundamental feature of Katz, its temporal orientation. None of the lower court opinions looked to eighteenth-century common law, or to history in general, for guidance; all of these opinions shared the focus of Katz on present-day concerns. They differed again, though, on a different question of temporal orientation, the degree to which they worried about the future. For the district court and for Judge Hawkins, the only important questions concerned the capabilities of thermal imagers to$d a y$-and, more particularly, the capabilities of the specific instrument used in the investigation of Danny Lee Kyllo. Judge Merhige and Judge Noonan made clear they found this

\footnotetext{
134 Id. at $1050-51$.

${ }_{165}$ The frequent references in the lower court opinions to the "non-intrusive" nature of thermal imaging are of course ambiguous: "intrusive" can mean either "physically invasive" or, more broadly, violating privacy in any way. The second panel opinion, written by Judge Hawkins, in fact took care to argue that the Thermovision 210 did not penetrate the walls of Kyllo's home either "literally or figuratively." Id. at 1046. But the frequent references by Judge Hawkins and by the district court to the way the device operated-projecting no rays or beams, and simply monitoring heat radiating from the outside surface of the home-strongly suggested that the absence of a "search" depended at least in part on the absence of a trespass.
} 
focus on the present too single-minded; they thought a sensible resolution of the case required some attention to what thermal imagers were likely to be able to do in the future. So while all of the lower court opinions in Kyllo were faithful to the temporal reorientation of Fourth Amendment law in Katz, they fought over the precise nature of that reorientation.

\section{B. Kyllo in the Supreme Court}

Writing for the four dissenters in Kyllo, Justice Stevens echoed each of themes the district court and Judge Hawkins had sounded below. He stressed the absence of any "physical penetration": ${ }^{156}$ thermal imagery, Justice Stevens noted repeatedly, is "off-the-wall" rather than "through-the-wall" surveillance. ${ }^{157} \mathrm{He}$ compared the heat emanating from a home to "discarded garbage," and to "aromas" that "enter the public domain if and when they leave a building. ${ }^{n 158} \mathrm{He}$ twice drew attention to the district court's finding that the surveillance in this case revealed "[n]o intimate details of the home." ${ }^{\text {"159 }}$ And he argued for "concentrating on the rather mundane issue" presented by the capabilities of the thermal imager used in this case, rather than trying "to craft an all-encompassing rule for the future." 160

Justice Stevens threw in some additional arguments. He distinguished, for example, between actually searching inside a home and merely drawing inferences about the inside of the home. ${ }^{161}$ And he suggested that there were strong practical reasons to keep surveillance techniques like thermal imaging constitutionally unregulated: the police, he argued, "should not have to avert their senses or their equipment from detecting

${ }^{136}$ Kyllo, 533 U.S. at 43 (Stevens, J., dissenting); see also id. at 45 (contrasting thermal imaging with "physical entry of the home") (quoting United States $v$. United States Dist. Court, 407 U.S. 297, 313 (1972)).

${ }^{157}$ Id. at $41-46,50-51$.

158 Id. at $43-44$.

${ }^{158}$ Id. at $41 \mathrm{n} .1,50$; see also id. at 43 (arguing that "no details regarding the interior of petitioner's home were revealed"), 45 (contending that "the privacy interest is at best trivial").

160 Id. at 51.

16r See id. at $42-44,50-51$. 
emissions in the public domain such as excessive heat, traces of smoke, suspicious odors, odorless gases, airborne particulates, or radioactive emissions, any of which could identify hazards to the community." ${ }^{\text {162 }}$ But both these points felt like filler. Neither made sense without the more basic contention that there was no reason to fear surveillance technology that was "non-intrusive," monitored emissions that no one could reasonably expect would remain private, and detected no "intimate details." The dissent in Kyllo added little of substance to the arguments advanced by Judge Hawkins for the Ninth Circuit and, before that, by the district court.

Justice Scalia's opinion for the majority was a different story. It, too, echoed themes sounded in the courts below, in this case by Judge Merhige and Judge Noonan. Justice Scalia stressed the fact that the surveillance here was of a home. ${ }^{163}$ He pointed out that Katz made the absence of a physical intrusion irrelevant. ${ }^{164} \mathrm{He}$ distinguished Dow Chemical on the ground that it involved surveillance of an industrial facility, "which does not share the Fourth Amendment sanctity of the home. ${ }^{165} \mathrm{He}$ made explicit what Judge Merhige and Judge Noonan had implied, that "[i]n the home ... all details are intimate details."166 And like Judge Merhige and Judge Noonan, Justice Scalia found a focus on the present capabilities of thermal imagers insufficient. "[T] he rule we adopt," he explained, "must take account of more sophisticated systems that are already in use or in development."167

But Justice Scalia added to these arguments in significant

103 Id. at 45 .

100 See id. at 31. Justice Scalia used the word "home" twice in the first sentence of his opinion, and three times in the next three sentences. Id. at 29. He quoted approvingly from the Court's announcement in Silverman v. United States, 365 U.S. 505, 511 (1961), that "[alt the very core' of the Fourth Amendment 'stands the right of a man to retreat into his own home and there be free from unreasonable governmental intrusion." 533 U.S. at 31 .

${ }^{134}$ Id. at $35-36$.

165 Id. at 37.

160 Id.

167 Id. at 36. This itself was a noteworthy divergence from previous decisions in which the Court had applied Katz to instruments of technological surveillance solely by measuring the current intrusion on privacy, leaving future threats to future cases. See supra note 70 and accompanying text. 
ways. His additions, in fact, are much of what is most arresting and important about the Court's opinion in Kyllo. For Justice Scalia took the opportunity in Kyllo to do what Judge Merhige and Judge Noonan likely did not feel free to do. He used the case to reconsider both the legacy of Katz and the proper relationship between the Fourth Amendment and common law.

Justice Scalia began this reconsideration by acknowledging that the "reasonable expectation of privacy" test set forth in Katz "has often been criticized as circular, and hence subjective and unpredictable." 168 He did not quarrel much with that criticism as a general matter-not a surprising failure, since he had made the criticism himself. ${ }^{169}$ But while Scalia agreed that overall the Katz test "may be difficult to refine," he suggested that in one context-searches of homes-there was a path out of the circularity. The path ran backwards in time to the common law:

[I]n the case of the search of the interior of homes-the prototypical and hence most commonly litigated area of protected privacy-there is a ready criterion, with roots deep in the common law, of the minimal expectation of privacy that exists, and that is acknowledged to be reasonable. To withdraw protection of this minimum expectation would be to permit police technology to erode the privacy guaranteed by the Fourth Amendment. ${ }^{170}$

Consequently, Justice Scalia announced for the Court that a "search" takes place whenever "sense-enhancing technology" gives the police information about the home they could otherwise obtain only by physical intrusion-“at least where (as here) the technology in question is not in general public use." ${ }^{171}$ The point, he explained, is to preserve "that degree of

Ky Kyllo, 533 U.S. at 34

160 See supra notes 83-84 and accompanying text.

170 Kyllo, 533 U.S. at 34.

17 Id. The Court appears to have taken this test from Professor James Tomkovicz's amicus brief for the ACLU and the National Association of Criminal Defense Lawyers. See Brief of Amicus Curiae of the National Association of Criminal Defense Lawyers and the American Civil Liberties Union at 26-27; Kyllo v. 
privacy against government that existed when the Fourth Amendment was adopted."

At first glance this looks like more of the new Fourth Amendment originalism: a continuation of the backward-looking approach to search-and-seizure law that Justice Scalia championed off and on throughout the 1990s, and that the Court finally endorsed in Wyoming $v$. Houghton. ${ }^{173}$ And there were more signs of this approach sprinkled throughout Justice Scalia's opinion for the Court in Kyllo. There was a reference to the meaning of the term "search" in the eighteenth century. ${ }^{174}$ There was an invocation of "the original meaning of the Fourth Amendment." ${ }^{175}$ There was a cranky remark about "our doctrine that warrantless searches are presumptively unconstitutional" and the Court's efforts to preserve that doctrine "somewhat more intact." ${ }^{176}$ And there was a reaffirmation of that presumption-but only as applied to searches of homes. ${ }^{177}$ It is easy to see why some observers thought the Court's opinion in Kyllo reactionary, "an ironic return to the pre-Katz world. ${ }^{178}$

But there was a good deal more to the decision than that.

United States, 533 U.S. 27 (2001) (No. 99-8508). As proposed in the amicus brief, however, the test lacked the caveat regarding technologies "in general public use." See id.

${ }^{172}$ Kyllo, 533 U.S. at 34.

173526 U.S. 295 (1999); see supra notes 74-93 and accompanying text.

174 Kyllo, 533 U.S. at 33 n.1. "When the Fourth Amendment was adopted, as now, to 'search' meant ' $[t]$ o look over or through for the purpose of finding something; to explore; to examine by inspection; as, to search the house for a book; to search the woods for a thief." Id. (quoting NOAH WEBSTER, AN AMERICAN DICTIONARY OF THE ENGLISH LANGUAGE 66 (1828) (reprint 6th ed. 1989)).

${ }^{175}$ Kyllo, 533 U.S. at 40.

178 Id. at 32.

177 See id. at 33. Even this limited reaffirmation of the warrant requirement was noteworthy, because it meant that calling thermal imaging of a home a "search" largely eliminated it as a law enforcement tactic. To get a warrant for thermal imaging the police will need probable cause that something illegal is occurring inside the house, and if they have that kind of probable cause, they can get a warrant to enter the house. In some cases they may prefer to use a thermal imager-if, for example, they want to keep the investigation secret for the time being. But those cases will be the exception rather than the rule.

${ }_{178}$ David Cole, Scalia's Kind of Privacy, Nation, July 23, 2001, at 6, available at 2001 WL 2132778. 
Justice Scalia's opinion did not reject Katz wholesale, nor did it embrace all of the new Fourth Amendment originalism. In each respect the position Justice Scalia took for the Court was more nuanced and more interesting.

Start with the treatment of Katz. True, Justice Scalia's emphasis on "the Fourth Amendment sanctity of the home"179 seems in tension with the idea that "the Fourth Amendment protects people, not places." But divergence from this aspect of Katz hardly started with Kyllo. Heightened Fourth Amendment protection in the home is a staple of search-and-seizure law, and the more general practice of tying Fourth Amendment privacy to particular places, Katz notwithstanding, stretches all the way back to Justice Harlan's concurring opinion in Katz itself. ${ }^{180}$ And Justice Scalia was conspicuously faithful to other aspects of Katz, particularly the holding that a Fourth Amendment violation can occur without a trespass or physical intrusion. ${ }^{181}$ Despite noting that "well into the 20 th century... Fourth Amendment jurisprudence was tied to common-law trespass," Scalia was unapologetic about the manner in which Katz "decoupled" search-and-seizure law from property rights, and he derided as "mechanical" the notion that the Fourth Amendment protects only against physical intrusions. ${ }^{182}$

Moreover, the skepticism Justice Scalia expressed about the "reasonable expectation of privacy" test was relatively muted, particularly compared with what he had said in earlier cases. The Court's opinion in Kyllo did not call Justice Harlan's test "self-indulgent" or charge that it lacked "plausible foundation in the text of the Fourth Amendment." The opinion conceded that "it may be difficult to refine Katz" when the test is applied to searches of "areas such as telephone booths, automobiles, or even the curtilage and uncovered portions of residences," but then suggested that for searches of homes-the core concern of the Fourth Amendment-the test produced a

178 Kyllo, 533 U.S. at 37.

180 See supra notes 57-68 and accompanying text.

181 See Kyllo, 533 U.S. at 32, 35.

182 Id. at $31,35$.

183 Minnesota v. Carter, 525 U.S. 83, 97 (1998) (Scalia, J., concurring). 
clear and sensible result. ${ }^{184}$ And Justice Scalia even cast a little doubt on the general criticism of the "reasonable expectation of privacy" test as circular-a criticism in which he himself had previously joined. After citing examples of this criticism, including his own, Justice Scalia pointedly added a "but see" reference to Rakas $v$. Illinois, where the Court had suggested that "legitimate expectations of privacy" were defined "by reference to concepts of real or personal property law or to understandings that are recognized and permitted by society. ${ }^{\prime 185}$ By tying reasonable expectations of privacy at least in part to property law, Rakas itself seemed to backtrack from the idea that "the Fourth Amendment protects people, not places." Again, though, that backtracking began in Katz itself, in the same concurring opinion that produced the "reasonable expectation of privacy" test.

Perhaps more significantly, Justice Scalia seemed in Kyllo to have grown more comfortable with the temporal reorientation of Fourth Amendment in Katz. He seemed less committed to anchoring the Fourth Amendment firmly in its past, at least in the manner he had previously proposed. In recent years, Justice Scalia and Justice Thomas repeatedly have turned for guidance in interpreting the Fourth Amendment to Chief Justice Taft's majority opinion in Carroll $v$. United States ${ }^{186}$ long familiar to students of criminal procedure as the source of the "automobile exception" to the warrant requirement, but not generally a favorite of the commentators. ${ }^{187}$ Scalia and Thom-

184 Kyllo, 533 U.S. at 34 (emphasis added). For a different assessment of this aspect of the Court's opinion, see Richard H. Seamon, Kyllo v. United States and the Partial Ascendance of Justice Scalia's Fourth Amendment, 79 WASH. U.L.Q. 1013 (2001) (available at http://papers.ssrn.com/sol3/papers.cfm?abstract_id=288415). Professor Seamon argues that Kyllo "at least weakly endorsed" earlier criticism of Katz, and that in fact "the Kyllo majority did not apply the Katz test to the case before it." Id. at 1022 . He reaches the latter conclusion because, like the Ninth Circuit and the district court, he believes that "the sole inquiry" under Katz "should have been whether Kyllo reasonably expected the relative warmth of his roof and a side of his house to remain private." Id.

${ }^{185}$ See Kyllo, 533 U.S. at 34 (citing Rakas v. Illinois, 439 U.S. 128, 143 n.12 (1978)).

186267 U.S. 132 (1925); see Sklansky, supra note 12, at 1766-67.

${ }^{187}$ See, e.g., LANDYNSKI, supra note 97, at 90; Forrest R. Black, A Critique of the Carroll Case, 29 ColuM. L. REv. 1068, (1929); Davies, supra note 23, at 604- 
as have invoked Carroll in support of the new Fourth Amendment originalism, but in doing so they have portrayed the opinion as more backward-looking that it really was. Taft wrote in Carroll that the Fourth Amendment should be "construed in the light of what was deemed an unreasonable search and seizure when it was adopted, and in a manner which will conserve public interests as well as the interests and rights of individual citizens. ${ }^{\prime 18}$ This is a test with considerable ambiguity: what happens when eighteenth-century search-and-seizure rules do not, in light of modern realities, "conserve public interests as well as the interests and rights of individual citizens"? Scalia and Thomas have tended to avoid the ambiguity by ignoring the second part of Taft's formulation. In one opinion, for example, Justice Scalia quoted Taft's test but simply left off the second half. ${ }^{189}$ But in Kyllo Justice Scalia quoted the entire sentence, ${ }^{190}$ and he seemed to take to heart Chief Justice Taft's commitment to a Fourth Amendment jurisprudence that bridged past, present and future-even at the cost of jurisprudential ambiguity. "We must take the long view," Scalia wrote for the Court, "from the original meaning of the Fourth Amendment forward."191

Notwithstanding its ambiguity, that sounds like a different approach to the Fourth Amendment than the one Justice Scalia set forth for the Court in Wyoming $v$. Houghton. ${ }^{192}$ One would think that taking "the long view" requires something other than simply checking to see if particular conduct "was regarded as an unlawful search or seizure under the common law when the Amendment was framed," and considering modern realities only if "that inquiry yields no answer."

08.

188 Carroll, 267 U.S. at 149 (emphasis added).

189 See Minnesota v. Dickerson, 508 U.S. 366, 379 (1993) (Scalia, J., concurring).

190 See Kyllo, 533 U.S. at 40. Professor Seamon has made the same point. See Seamon, supra note 184, at 1032.

191 Kyllo, 533 U.S. at 40; cf. United States v. Ross, 456 U.S. 798, 806 (1982)

(nicely capturing the ambiguity of Carroll by describing the case as grounded in considerations of "impracticability, viewed in historical perspective").

192526 U.S. 295 (1999).

190 Houghton, 526 U.S. at 299-300. 
Justice Scalia's opinions for the Court in Houghton and Kyllo are not mutually inconsistent. But the opinions differ sharply in tone, and the underlying sensibility in Kyllo is far less backward-looking than in Houghton. For this reason alone, Kyllo seems in tension with the new Fourth Amendment originalism.

And there is more. Although Justice Scalia invokes common law in Kyllo, he does so in a different way than in Houghton. The Court's opinion in Kyllo does not look to the content of eighteenth-century rules of search and seizure; rather it looks to what those rules accomplished. The goal, Justice Scalia explains, is to guarantee "preservation of that degree of privacy against government that existed when the Fourth Amendment was adopted. ${ }^{194}$ This is a different enterprise than preserving the rules that existed when the Amendment was adopted, because changing conditions may mean that new restrictions are required to maintain old expectations of privacy against the government. The central question in Kyllo, Justice Scalia wrote, was "what limits there are upon this power of technology to shrink the realm of guaranteed privacy. ${ }^{m 195}$ The very framing of the historical inquiry in Kyllo, therefore, was less resolutely backward-looking than the analysis mandated by Houghton.

As actually carried out by Justice Scalia, moreover, the Kyllo inquiry was even looser. For Justice Scalia made no effort in Kyllo to determine the actual degree of privacy Americans enjoyed against the government in 1789 . This was probably wise, because the question turns out to have no simple answer. In fact, the "degree of privacy against government that existed when the Fourth Amendment was adopted" turns out to be even less determinate than whether particular conduct "was

194 Kyllo, 533 U.S. at 34. Justice Scalia had made a similar claim in his concurring opinion in Minnesota v. Dickerson, 508 U.S. 366 (1993). There he had written that the purpose of the Fourth Amendment was "to preserve that degree of respect for the privacy of persons and the inviolability of their property that existed when the provision was adopted." Id. at 380 (Scalia, J., concurring). But Scalia's analysis in Dickerson suggested what he elsewhere had made explicit, and what he later spelled out for the Court in Houghton: that the way to preserve eighteenth-century privacy was, in general, by applying eighteenth-century rules of search and seizure. See Sklansky, supra note 12, at 1754-61.

196 Kyllo, 533 U.S. at 34. 
regarded as an unlawful search and seizure under the common law when the Amendment was framed." The problem is that the "degree of privacy" people enjoyed in the eighteenth century, even inside their own homes, depended strongly on who they were. ${ }^{196}$ In England, peers and members of Parliament received special protections against search and seizure, while the homes of the poor were freely examined for vagrants, poached game, and morals violations. ${ }^{197}$ Colonial statutes largely followed the same pattern and added, in the South, the innovation of the slave patrol: military squads that routinely invaded "Negro Houses" and other dwellings that might harbor or provide arms to runaway slaves. ${ }^{198}$ And on both sides of the Atlantic, political outsiders often found themselves with little or no privacy against the government-unless and until they became insiders, at which time they energetically employed against their own adversaries the same tactics they previously had condemned. ${ }^{199}$

Had Justice Scalia attempted a rigorous inquiry into the "degree of privacy" Americans enjoyed in their houses in 1789, he would have had great difficulty coming up with a clear answer. But he entirely avoided this problem, because he made no serious effort to describe eighteenth-century realities. Instead he contented himself with an invocation of the general notion of the "sanctity of the home," noted, had "roots deep in the common law." 201 He was concerned less with history than with tradition, less with what the

${ }^{190}$ See Cloud, supra note 23, at 1717-19.

197 See Cuddihy, supra note 23 , at $43,187,668,831$; William Cuddihy \& B. Carmon Hardy, A Man's House Was Not His Castle: Origins of the Fourth Amendment to the United States Constitution, 37 WM. \& MARY Q. 371, 380 (1980). Even the fiercest critics of general warrants typically took for granted the legality of warrantless inspections for vagrants, as well as warrantless searches for evidence of treason. See Cuddihy, supra note 23, at 987-90.

196 See LEONARD W. LEVY, ORIGINAL INTENT AND THE Framers' Constitution 240 (1988); Cuddihy, supra note 23, at 838-39, 867, 1150-53, 1276-95, 1327; Cuddihy \& Hardy, supra note 197, at 390-91. On slave patrols, see SAlly E. Hadden, Slave Patrols: Law and Violence in Virginia and the Carolinas (2001).

${ }^{199}$ See, e.g., Cloud, supra note 23, at 1717-18.

200 Kyllo, 533 U.S. at 37.

201 Id. at 34 . 
law actually did than with what the law came to understand itself as doing, and to claim that it had always done.

Creating tradition out of reinvented history is a familiar method of jurisprudence, a method that itself dates back at least to Coke's seventeenth-century Institutes. ${ }^{202}$ In particular, it is a method long associated with search-and-seizure law. ${ }^{203}$ The most famous argument against the writs of assistance in colonial America-the failed challenge by James Otis in 1761 to renewal of the writs in Massachusetts-leaned heavily on history, but in a manner sometimes less sensitive to factual accuracy than to rhetorical coherence. ${ }^{204}$ Justice Bradley's majority opinion in Boyd $v$. United States, ${ }^{205}$ the Court's first major interpretation of the Fourth Amendment, also extracted broad principles from the past; it, too, is commonly praised not as historical scholarship, but as an exercise of legal creativity. ${ }^{206}$ And there is a large element of fiction in the new Fourth Amendment originalism embraced by the Court in Houghton. The approach Houghton took to the Fourth Amendment-an approach Justice Scalia had championed throughout the 1990 s-proceeds from the assumption that the common law of search and seizure was fixed, uniform, consistent and clear. In fact, as I have argued elsewhere, it was none of those things. ${ }^{207}$

The Court's looseness with history in Kyllo, therefore, does not distinguish the decision from Houghton, or from the new Fourth Amendment originalism more generally. But the Court in Kyllo was more forthright about what it was doing-or, at least, it engaged in less pretense that its inquiry was strictly empirical. The new Fourth Amendment originalism cloaks

${ }^{202}$ See H. Trevor Colbourn, The LAMP OF EXPERIENCE: Whig History AND THE INTEllectual ORIGiNS OF the AMerican Revolution 8 (1965); James R. STONER, JR., COMmON LAW aNd LIBERAL THEORY: COKE, HOBBES, AND THE ORIGINS OF AMERICAN CONSTITUTIONALISM 62-68 (1992); William Holdsworth, Sir Edward Coke, 5 CAMBRIDGE L.J. 332, 340-42 (1935); Cuddihy, supra note 23, at 215-33.

${ }^{203}$ See Sklansky, supra note 12 , at 1753.

204 See LEVY, supra note 198, at 227; Cuddihy, supra note 23, at 788-89.

206116 U.S. 616 (1886).

${ }^{206}$ See, e.g., LANDYNSKI, supra note 97, at 60-61.

207 See Sklansky, supra note 12 , at 1795-1807. 
questions of fairness and expediency as scholarly disputes about eighteenth-century common law. Justice Scalia's opinion for the Court in Houghton, like some of his earlier concurring and dissenting opinions in Fourth Amendment cases, and like Justice Thomas's majority opinion in Wilson $v$. Arkansas, ${ }^{208}$ often verged on the pedantic. "Trust me," these opinions seemed to say, "I've been to the library." That complaint cannot be made about Kyllo. There is nothing recondite about the Court's analysis of thermal imaging. Justice Scalia is explicit about the need to interpret the Fourth Amendment in ways that take account of scientific progress and that offer "workable," "practical guidance." ${ }^{209}$ Coke, Hale and Blackstone make no appearance. The earliest decisions cited are Boyd and Olmstead-and neither case for guidance regarding what the law is or should be, but rather as sources of the "mechanical" view, now properly rejected, that a search requires a trespass. $^{210}$

The only aspect of common law that Justice Scalia invokes in Kyllo is one for which he sees no need to cite any ancient authority: the "deep roots" of the notion that privacy within the home deserves special protection. ${ }^{211}$ That proposition needs no archival support not just because Justice Stevens, in particular, could not be expected to challenge it. ${ }^{212}$ It needs no such support because it is an assertion less about history than about tradition-i.e., about the meaning that Fourth Amendment doctrine, developed incrementally over decades by the Supreme Court, has come to attach to history. This kind of tradition is itself a time-honored focus of Fourth Amendment jurisprudence, including the opinions that Justice Scalia himself wrote in search-and-seizure cases during his first several years on the Court. In this respect, as well as others, Kyllo represents something of a return-but a return to a jurisprudence less an-

208514 U.S. 927 (1995); see supra note 87 and accompanying text.

${ }^{309}$ Kyllo, 533 U.S. at 38-39 (quoting Oliver v. United States, 466 U.S. 170, 181 (1984)).

210 Id. at 32,35 .

211 Id. at $37-40$.

212 See supra note 109. 
chored in the past.

\section{THE ConNotations OF KYLLO}

Kyllo is less important for its result than for its jurisprudence. Justice Scalia's majority opinion works variations both on Katz and on the Court's recent turn toward common law for guidance in interpreting the Fourth Amendment. I have described those variations above, and now wish to assess their merits and long-term implications. I take up first the connotations of Kyllo for the new Fourth Amendment originalism, which are relatively straightforward, and then turn to the murkier implications of the decision for the legacy of Katz.

\section{A. Common Law}

Despite Justice Scalia's reference to "the original meaning of the Fourth Amendment" ${ }^{\text {213 }}$ and his invocation of a "criterion ... with roots deep in the common law, ${ }^{, 214}$ the use of common law in $K y l l o$ departs in two significant ways from its use in Houghton and in other opinions applying the new Fourth Amendment originalism. First, $K y l l o$ asks a different question about the past: not whether the challenged government conduct would have constituted an illegal search or seizure at common law, but whether the conduct, if constitutionally unregulated, would "shrink the realm of . . privacy ... that existed when the Fourth Amendment was adopted." ${ }^{215}$ Second, Kyllo goes about answering its question in a different way. The inquiry is less about history than about tradition.

Taken together, these two changes transform the new Fourth Amendment originalism from an effort to preserve eighteenth-century rules of search and seizure into an attempt to safeguard what the Court has come to understand to be the core components of the privacy valued by the Framers. These changes shift the Court's attention from the form that government conduct takes to the nature and degree of the intrusion it

213 Kyllo, 533 U.S. at 40.

214 Id. at 34.

215 Id. 
effects, and from eighteenth-century history to the Court's own evolving traditions.

They bring the Court remarkably close, in fact, to the question Anthony Amsterdam found lying beneath the surface of the decision in Katz: "whether, if the particular form of surveillance practiced by the police is permitted to go unregulated by constitutional restraints, the amount of privacy and freedom remaining to citizens would be diminished to a compass inconsistent with the aims of a free and open society." ${ }^{216}$ Substitute "our traditions" for "a free and open society," and Amsterdam's test becomes Scalia's. Of course this is hardly a trivial substitution. Amsterdam's view of search-and-seizure law untethered it almost entirely from history-the Court's own history as well as the history of the Fourth Amendment. ${ }^{217}$ Fidelity to tradition imposes real constraints, albeit constraints that typically leave some wiggle room. ${ }^{218}$ Still, the similarity between Amsterdam's test and the reconfigured common-law inquiry in Kyllo is illuminating. It throws into sharp relief the degree to which Kyllo seems to abandon the effort to render Fourth Amendment law stable, determinate and independent of judicial predilection by anchoring it in eighteenth-century common law.

Precisely for that reason, it is hard to know how much to read into this aspect of Kyllo. When push comes to shove, the Court may well balk at determining the scope of the Fourth Amendment by reference to something as open-ended as "tradition." Perhaps deep down the Court even now remains as committed as it was in Houghton to the new Fourth Amendment originalism. Or perhaps Justice Scalia remains committed, but he had to tailor his opinion in Kyllo to reflect qualms developed by other members of the Court. ${ }^{219}$ Or maybe even Justice

\footnotetext{
${ }^{216}$ Amsterdam, supra note 13, at 403; accord, e.g., 1 WAYNE R. LAFAVE, SEARCH AND SEIZURE \& 2.7(a), at 621 (3d ed. 1996).

${ }^{217}$ See Carol S. Steiker, Of Cities, Rainforests, and Frogs: A Response to Allen and Rosenberg, 72 ST. JoHN'S L. REv. 1203, 1204 (1998).

218 See Sklansky, supra note 12, at 1808-09.

${ }^{219}$ Cf. Seamon, supra note 184, at 1025 (suggesting that Justice Scalia's opinion in Kyllo tempered his own views because the Court as a whole does not fully support them).
} 
Scalia has retreated somewhat from the views reflected in Houghton. For anyone who has found the use of common law in the Court's recent Fourth Amendment decisions wooden and bordering on the pedantic, Kyllo points in a hopeful direction. For reasons to be discussed below, the direction Kyllo provides regarding the proper role of tradition in interpreting the Fourth Amendment also could help the Court make better sense of Katz. But whether the Court actually will follow that direction remains unclear.

\section{B. Katz}

Despite its striking allegiance to certain aspects of Katz, Justice Scalia's opinion for the Court in Kyllo raises two serious questions about the earlier decision. First, is it faithful to Katz, and is it wise to rest Fourth Amendment analysis so heavily on the location of surveillance-in particular, on the fact that the subject of surveillance is at home? Second, how should the Court answer the question Justice Scalia deliberately left open in Kyllo: whether the use of new technology to spy on people at home can violate a "reasonable expectation of privacy" even when the technology is "in general public use"? ${ }^{220}$ I consider each of these questions in turn.

\section{1. "People, Not Places" and the "Sanctity of the Home"}

Ever since Katz, the Supreme Court has repeatedly reaffirmed two basic propositions about the Fourth Amendment. The first is that the protection the Amendment provides is independent of location. ${ }^{221}$ The second is that the Amendment provides special protection to the home. ${ }^{222}$ Each of these ideas has obvious appeal. But they are mutually inconsistent.

Kyllo resolves them the way Justice Harlan resolved them in his concurring opinion in Katz: by opting for the second proposition rather than the first. For Justice Harlan, the

\footnotetext{
220 Kyllo, 533 U.S. at 34.

221 See supra note 66 and accompanying text.

222 See supra note 67 and accompanying text.
} 
Fourth Amendment protected "people, not places" only in the most banal sense: places would not be heard to complain about Fourth Amendment violations, only people. But whether a person's complaint had merit would generally depend heavily, Justice Harlan thought, on where the search or seizure occurred. Thus the telephone surveillance in Katz violated the Fourth Amendment only because in relevant respects a telephone booth was "like a home." S23 Similarly, the majority opinion in Kyllo repeatedly emphasizes that the thermal imager was aimed at a residence. Indeed, Justice Scalia's endorsement of the "reasonable expectation of privacy" test is limited to "the case of the search of the interior of the home."224 So, too, Justice Scalia reaffirms that warrantless searches of homes generally are "unreasonable" and hence unconstitutional, but he goes out of his way to cast doubt on the broader proposition that all warrantless searches are "presumptively unconstitutional. ${ }^{225}$

There is a good deal to be said for giving homes special status under the Fourth Amendment. Homes are different than other places. It is not just the long legal tradition of singling out homes for particular protection-a tradition reflected in the wording of the Fourth Amendment itself, in the earlier history of search and seizure law, and in ancillary doctrines such as the crime of burglary. Wholly aside from that tradition, there does seem something particularly objectionable about being harassed at home-even without a trespass. That is why telephone solicitors are so deeply resented. And, similarly, there is something particularly objectionable about being spied on at home, even without a trespass. Orwell's 1984 would have much less frightening if Big Brother's surveillance apparatus did not reach into the home. The ability to enjoy solitude in one's home

${ }^{223}$ Katz, 389 U.S. at 360-62 (Harlan, J., concurring).

224 Kyllo, 533 U.S. at 34.

225 Id. at 32. As Professor Seamon points out, the narrow reaffirmation of the warrant requirement in Kyllo is consistent with the Court's tacit retreat over the past decade from the notion that all searches presumptively require warrants-a retreat that may have been prompted, in part, by Justice Scalia's criticism of the warrant requirement in his concurring opinion in United States v. Acevedo, 500 U.S. 565, 583 (1991). See Seamon, supra note 184, at 1027-28. 
seems both a aspect of human dignity and a prerequisite of a free society. As the Court stressed in a precursor to Katz, a "sane, decent, civilized society must provide some such oasis, some shelter from public scrutiny, some insulated enclosure, some enclave, some inviolate place. ${ }^{226}$

Of course there are costs to treating the home differently than other places. If privacy receives more protection in the home than elsewhere, it necessarily follows that leaving one's home means losing some privacy - that the price of full privacy is not going out. That price might impair rather than foster a free and vibrant society. Moreover, the price is not visited equally on everyone, because not all homes are equivalent. As Professor William Stuntz has recently reminded us, rich people have bigger and more comfortable homes than poor people; it is therefore much easier for rich people than for poor people to stay home when engaged in activities they wish to keep private. Granting homes more privacy than other places therefore tilts Fourth Amendment protection in favor of the rich and against the poor, who are forced to conduct much of their lives outside of their residences. ${ }^{227}$

${ }_{228}$ Silverman v. United States, 365 U.S. 505, 511 n.4 (1961) (quoting United States v. On Lee, 193 F.2d 306, 315-16 (2d Cir. 1951) (Frank, J., dissenting), affd, 343 U.S. 747 (1952)); see also, e.g., James J. Tomkovicz, Beyond Secrecy for Secrecy's Sake: Toward an Expanded Vision of the Fourth Amendment Privacy Province, 36 HASTINGS L.J. 645, 673-75 (1985).

Silverman found the Fourth Amendment violated when federal agents attached a microphone to the defendants' heating duct and thereby "usurp[ed] part of [their] home or office." Silverman, 365 U.S. at 511. Justice Stewart's majority opinion stressed that the case required no reconsideration of Olmstead, because "the eavesdropping was accomplished by means of an unauthorized physical penetration into the premises occupied by the petitioners," regardless whether there was "a technical trespass under the local property law relating to party walls." Id. at 509, 511. Later, though, writing for the Court in Katz, Justice Stewart pointed to Silverman as one of the decisions that had "so eroded" the "underpinnings of Olmstead" that "the 'trespass' doctrine there enunciated can no longer be considered as controlling." Katz, 389 U.S. at 353.

Notwithstanding the appreciation the Court showed in Silverman for Judge Frank's dissent in On Lee, the Justices have never wavered from the ruling they affirmed in that case: that the Fourth Amendment is not implicated by electronic monitoring of an undercover meeting with a criminal suspect, even in the suspect's home or office. See United States v. White, 401 U.S. 745, 750-54 (1971).

${ }^{237}$ See William J. Stuntz, The Distribution of Fourth Amendment Privacy, 67 GEo. WASH. L. REV. 1265, 1270 (1999); see also, e.g., Amsterdam, supra note 13, 
Many advocates of greater privacy against the police therefore have little enthusiasm for the notion that the home is a castle. They worry this means "the streets ... belong to the police. ${ }^{2228}$ But there is little reason to believe that erasing the boundary between the home and the street would give streets as much privacy as homes, instead of giving homes as little privacy as streets. The Supreme Court has rarely taken Fourth Amendment protections for the home and extended them to other locales: Katz is highly unusual in this respect. More commonly, the Court's failure to distinguish between the home and areas outside the home has resulted in diminished privacy protection for the home. When the Court approved "protective sweeps" of homes, for example, it analogized to the similar practice it had earlier authorized for automobiles, ${ }^{229}$ and discounted references in the dissent to "the special sanctity of a private residence. ${ }^{230}$ So, too, when the Court first approved warrantless searches of the homes of probationers, it drew on decisions permitting warrantless searches based on "special needs" in schools, prisons, and government offices ${ }^{231}$-and again left it to the dissent to stress that " $[t]$ he search in this case was conducted in petitioner's home, the place that traditionally has been regarded as the center of a person's private life, the bastion in which one has a legitimate expectation of privacy protected by the Fourth Amendment. ${ }^{\text {n232 }}$ And similar-

at 404 .

223 Cole, supra note 178. Professor Seamon hints at a similar concern when he warns that the Supreme Court's decision in Kyllo may "signal a balkanization of the Fourth Amendment." See Seamon, supra note 184, at 1029.

239 See Maryland v. Buie, 494 U.S. 325, 332 (1990).

230 Id. at $342-43$ (Brennan, J., dissenting).

${ }^{231}$ Griffin v. Wisconsin, 483 U.S. 868, 873-74 (1987).

${ }^{232}$ Griffin, 483 U.S. at 883 (Blackmun, J., dissenting). More recently, in United States v. Knights, 534 U.S. 112 (2001), the Court approved warrantless probation searches not based on a theory of "special needs" but rather by applying the general "balancing" approach of Terry v. Ohio, 392 U.S. 1 (1968)-a test initially crafted to help regulate "the myriad daily situations in which policemen and citizens confront each other on the street." Id. at 12; see supra notes 37-46 and accompanying text. In applying Terry to searches of automobiles, the Court has stressed that the balancing must take into account "the totality of the circumstances," Ohio v. Robinette, 519 U.S. 33, 39 (1996), and this principle, too, was applied to the residential search at issue in Knights. See Knights, 534 U.S. at 
ly, when the Court held that a short-term guest in another's home may lack any reasonable expectation of privacy, ${ }^{233}$ it was extending into the home its earlier ruling that a passenger in someone else's automobile cannot challenge a search of the vehicle. ${ }^{234}$ In practice, there is something of an inverse relation between the scope of the Fourth Amendment and the protection that it offers. ${ }^{235}$ To say that it applies everywhere equally is to say that it protects nowhere very strictly. ${ }^{236}$

The Court therefore had good reason in Kyllo to emphasize "the Fourth Amendment sanctity of the home,"237 just as Justice Harlan had good reason in Katz to insist that the protection provided by the Fourth Amendment "generally ... requires reference to a 'place. ${ }^{m 238}$ The problem remains how to reconcile this focus on location with the result in Katz. Justice Harlan's answer-that an enclosed telephone booth can be analogized to a house-was unpersuasive at the time and, with cellular telephones and unenclosed pay telephones rapidly replacing telephone booths, is even less persuasive now. ${ }^{239}$ Surely what mattered was not that Katz was in a telephone

118. Once again, Fourth Amendment rules developed for the street were applied to the home.

23s See Minnesota v. Carter, 525 U.S. 83 (1998).

234 Rakas v. Illinois, 439 U.S. 128 (1978); see also Carter, 525 U.S. at 108 (Ginsburg, J., dissenting) (noting that Rakas "tolerates" the risk that police officers will be tempted to search automobiles illegally in the hope of finding evidence admissible against suspects who cannot challenge the search, but seeing "no impelling reason to extend this risk into the home").

${ }_{235}$ See, e.g., Amsterdam, supra note 13, at 387-88, 405.

${ }^{2 s 6}$ This is merely one instance of the familiar, more general phenomenon that broadening the scope of a legal protection puts downward pressure on its rigor. Another example from criminal procedure: The Miranda rules were initially crafted for stationhouse interrogations, see Miranda v. Arizona, 384 U.S. 436, 444 (1966), and only afterward extended, over sharp dissents, to "custodial" questioning in other, less coercive settings, see Orozco v. Texas, 394 U.S. 324 (1969); Mathis v. United States, 391 U.S. 1 (1968). It is unlikely to be a coincidence that most of the subsequent decisions weakening Miranda-by carving out exceptions to its requirements, limiting the remedies for its violation, and casting doubt on its constitutional status-involved questioning in the field rather than in interrogation rooms. See, e.g., Oregon v. Elstad, 470 U.S. 298 (1985); New York v. Quarles, 467 U.S. 649 (1984); Harris v. New York, 401 U.S. 222 (1971).

237 Kyllo, 533 U.S. at 37.

238 Katz, 389 U.S. at 361 (Harlan, J., concurring).

${ }^{239}$ See supra notes 63-65 and accompanying text. 
booth, but that he was making a telephone call.

The key to reconciling Katz with the longstanding centrality of the home in Fourth Amendment law is precisely this intuition that the privacy protected in Katz attached neither to a person (Charles Katz), nor to a place (the telephone booth), but to a communication (the telephone conversation). Katz had a reasonable expectation of privacy neither because of who he was nor because of where he was, but because of what he was doing. Justice Harlan may well have been right that the trigger for Fourth Amendment protection is generally a location-but not always, and not in Katz. ${ }^{240}$ The core meaning of Katz, as Justice White once wrote for the Court, is "that the Fourth Amendment protects a person's private conversations as well as his private premises. ${ }^{\text {241 }}$

The relevant analogy in Katz therefore was not between telephone booths and homes but between telephone calls and letters-a more traditional form of communication at a distance, for which Fourth Amendment protection had long been settled. The text of the Fourth Amendment specifically guarantees the security of "papers," along with "persons, houses, ... and effects," and there is a celebrated tradition, on both sides of the Atlantic, of treating papers as a person's "dearest property. ${ }^{242}$ Drawing on this tradition, the Supreme Court held as early as 1878 that the Fourth Amendment barred warrantless

240 Similarly, the privacy the Court has protected as a matter of substantive due process can usefully be understood as sometimes attaching "to certain places without regard for the particular activities in which the individuals who occupy them are engaged," and other times attaching "to certain decisions that are properly for the individual to make." Bowers v. Hardwick, 478 U.S. 186, 203-04 (1986) (Blackmun, J., dissenting).

241 Alderman v. United States, 394 U.S. 165, 178 (1969); cf., e.g., Peter Arenella, Rethinking the Functions of Criminal Procedure: The Warren and Burger Courts' Competing Ideologies, 72 GEo. L.J. 185, 201 (1983) (suggesting that the Fourth Amendment protects distinct interests in "informational privacy, privacy of place, and physical privacy") (footnotes omitted).

${ }^{242}$ Boyd v. United States, 116 U.S. 616, 627-28 (1886) (quoting Entick v. Carrington, 95 Eng. Rep. 807 (C.P. 1765)); accord, United States v. Lefkowitz, 285 U.S. 452, 465 (1932); see Morgan Cloud, The Fourth Amendment During the Lochner Era: Privacy, Property and Liberty in Constitutional Theory, 48 STAN. L. REV. 555, 589-96 (1996); Eric Schnapper, Unreasonable Searches and Seizures of Papers, 71 VA. L. REV. 869 (1985). 
searches of mail "intended to be kept free from inspection, such as letters, and sealed packages subject to letter postage. ${ }^{\text {243 }}$ The government was free to observe the "outward form and weight" of such items, but it could open and examine them only after satisfying the same requirements imposed "when papers are subjected to search in one's own household." 244 The Court later rejected the notion that papers have "special sanctity" under the Fourth Amendment, ${ }^{245}$ and of course Katz repudiated the broader notion that the Fourth Amendment serves chiefly to protect certain property rights. But in the wake of Katz the Court reaffirmed that the Fourth Amendment protects private correspondence from warrantless inspection. ${ }^{246}$ In doing so the Court stressed the significance of mail not as a form of property, not as part of a person's "papers," but rather as a medium of communication:

The course of events since 1878 has underlined the relevance and importance of the Post Office to our constitutional rights. Mr. Justice Holmes in United States ex rel. Milwaukee Social Democratic Pub. Co. v. Burleson, 255 U.S. 407, 437 (dissenting opinion), said that "the use of the mails is almost as much a part of free speech as the right to use our tongues." We have emphasized over and over again that while Congress may classify the mail and fix the charges for its carriage, it may not set up regimes of censorship over it, Hannegan $v$. Esquire, Inc., 327 U.S. 146, nor encumber its flow by setting "administrative officials astride the flow of mail to inspect it, appraise it, write the addressee about it, and await a response before dispatching the mail" to him. Lamont $v$. Postmaster General, 381 U.S. 301, 306. ${ }^{247}$

Of course the Fourth Amendment does not protect the privacy of all communications. A police officer needs no warrant, nor any other constitutional prerequisite, to read an edi-

243 Ex parte Jackson, 96 U.S. 727, 733 (1878).

241 Id.

245 Gouled v. United States, 255 U.S. 298, 309 (1921); see Cloud, supra note 242, at 592-93.

248 United States v. Van Leeuwen, 397 U.S. 249 (1970).

247 Van Leeuwen, 397 U.S. at 251-52 (footnote omitted). 
torial published in a newspaper or to listen to a public lecture. Perhaps the Fourth Amendment likewise should not apply to the inspection of a postcard, which carries its message as part of its "outward form," subway car, or-as lower courts have held-to telephone conversations capable of being overheard in public without the use of any sensory enhancement. ${ }^{249}$ Saying the Fourth Amendment protects some communications does not tell us which communications, anymore than saying it protects some places tells us which places. Some additional analysis is needed to identify the communications people can reasonably expect the government to treat as private, just as some additional analysis is needed to identify the places where such an expectation of privacy generally will be reasonable.

As we have seen, Kyllo answers the latter question in part by appealing to tradition. Scalia's majority opinion in Kyllo appeals both to the narrow tradition of the home as a citadel of privacy and, implicitly, to the wider realm of privacy valued by the Framers of the Fourth Amendment. ${ }^{250}$ The Court made similar appeals to narrow and broad traditions in reaffirming the privacy of posted letters in the wake of Katz: to the narrow tradition of the protecting first-class mail under the Fourth Amendment, and to the broad tradition of unfettered speech. And appeals of the same kind offer the strongest justification for the result in Katz itself. The narrow point is that telephone calls are in many respects the modern equivalent of eighteenthcentury letters ${ }^{251}$-something the Court itself hinted at in

${ }^{248}$ See Note, Keeping Secrets in Cyberspace: Establishing Fourth Amendment Protection for Internet Communication, 110 HARv. L. REv. 1591, 1597 (1997). Lower courts have found the Fourth Amendment inapplicable when law enforcement agents systematically record the information appearing on the outside of mail sent to a particular suspect, a tactic known as a "mail cover." See, e.g., 1 LAFAVE, supra note 183, \& 2.7(a), at 618-22; Note, supra, at 1597 n.62.

${ }^{248}$ See, e.g., United States v. Muckenthaler, 584 F.2d 240 (8th Cir. 1978); United States v. McLeod, 493 F.2d 1186 (7th Cir. 1974); State v. Constantino, 603 A.2d 173 (N.J. Super. 1991); People v. Fisher, 420 N.W.2d 858 (Mich. App. 1988); State v. Kuznitz, 250 A.2d 802 (N.J. Super. 1969).

${ }^{250}$ See supra notes 213-18 and accompanying text.

251 On the importance of this kind of "translation" in constitutional interpretation, see Lawrence Lessig, Fidelity in Translation, 71 TEX. L. REv. 1165 (1993). 
Katz by stressing "the vital role that the public telephone has come to play in private communication. ${ }^{\text {252 }}$ The broader point is that "the insidious, far-reaching and indiscriminate nature of electronic surveillance-and, more important, its capacity to choke off free human discourse that is the hallmark of an open society-makes it almost, although not quite, as destructive of liberty, as "the kicked-in door."253

The newly pervasive metaphor of cyberspace may make all of this easier to see now than when Katz was decided. ${ }^{254}$ Within the past decade, we have grown used to thinking of internet users as occupying not only physical locations-chairs in front of computer screens-but also metaphoric, or "virtual" locations-chat rooms, web sites, etc. It no longer seems odd to speak of "breaking into" a remote database or "lurking in" a discussion group. ${ }^{255}$ If the government wanted to monitor surreptitiously the keyboard strokes of a twenty-first-century Katz connected to the internet through a pay telephone, it might seem natural to ask, in assessing the suspect's claim of privacy, not only where he was sitting but where he was "visiting." And in hindsight it makes sense to ask this about the Katz case as

The principal target of the influential dissent filed by Justice Brandeis in Olmstead v. United States, 277 U.S. 438 (1928), was precisely the Court's "unduly literal construction" of the Fourth Amendment, limiting its reach to searches and seizures of "persons, houses, papers, and effects." Olmstead, 277 U.S. at 476; see, e.g., Clancy, supra note 67, at 317-20, 325-26.

${ }_{252}$ Katz, 389 U.S. at 352.

25s Amsterdam, supra note 13 , at 388 (endnotes omitted).

2st See, e.g., Jerry Kang, Information Privacy in Cyberspace Transactions, 50 STAN. L. REV. 1193 (1998); Lawrence Lessig, Reading the Constitution in Cyberspace, 45 EMORY L.J. 869 (1996); Laurence H. Tribe, The Constitution in Cyberspace: Law and Liberty Beyond the Electronic Frontier, Mar. 26, 1991 (unpublished manuscript on file with author and available at http://www.epic.org/free_speech/tribe.html (last visited Aug. 28, 2002)). But cf. Note, supra note 257, at 1599 (cautioning that "[b]ecause the architecture of cyberspace is dissimilar to most conventional notions of place, analogizing cyberspace to a place for purposes of the Fourth Amendment has serious limitations").

${ }^{236}$ Cf. Christopher Slobogin \& Joseph E. Schumacher, Reasonable Expectations of Privacy and Autonomy in Fourth Amendment Cases: An Empirical Look at "Understandings Recognized and Permitted by Society," 42 DUKE L.J. 727, 739 (1993) (reporting that survey participants found "[t]apping into a corporation's computer" almost as "intrusive" as searching a college dormitory room). 
well. Cyberspace, after all, has been memorably described as "that place you are in when you are talking on the telephone. ${ }^{\text {256 }}$ And that, not the telephone booth, was the "place" that warranted privacy protection in Katz.

The advent of the internet makes this not only easier to see but also more important to recognize. Many of the predictions about the coming cyber-society are clearly overblown. But many of us are conducting more and more of our lives online, and the trend seems likely to continue, albeit less rapidly then is sometimes claimed. ${ }^{257}$ Telephone calls no longer are the most obvious modern analog to eighteenth-century letters; email is. Likewise, we now use the worldwide web for much of what used to entail an afternoon at the library or a trip to a department store. And, perhaps more important, what we do online can be monitored far more completely and systematically than most of what we do away from our computers. ${ }^{258}$ So the widespread use of the internet as a medium of social, political, and commercial interaction poses very real challenges for search-and-seizure law. Given "the vital role" this new medium "has come to play in private communication," protected by the Fourth Amendment-even more, perhaps, than leaving wiretapping constitutionally unregulated-seems "inconsistent with the aims of a free and open society." ${ }^{260}$ But the structure of the internet-particularly the manner in which internet communications typically leave trails in many different computers, one or more of which the government will often

${ }^{25 s}$ Philip Elmer-DeWitt, Welcome to Cyberspace: What Is It? Where Is It? And How Do We Get There?, TmE, Mar. 22, 1995, at 4, 8 (quoting John Perry Barlow); see also, e.g., Tribe, supra note 254; Michael Adler, Note, Cyberspace, General Searches, and Digital Contraband: The Fourth Amendment and the NetWide Search, 105 YALE L.J. 1093, 1102 (1996) (calling Olmstead v. United States "arguably . . . the Court's first foray into the jurisprudence of cyberspace").

${ }_{257}$ See, e.g., Adler, supra note 256, at 1096; Note, supra note 248, at 1607-08.

258 See, e.g., Kang, supra note 254, at 1224-29; Jessica Litman, Information Privacy/Information Property, 52 STAN. L. REV. 1283, 1283-84 (2000); Adler, supra note 256 , at $1095-96$.

${ }_{258}$ Katz, 389 U.S. at 352.

260 Amsterdam, supra note 13, at 403; see, e.g., Lessig, supra note 254; Tribe, supra note 254. 
have consent to access ${ }^{261}$-means that much if not most government snooping in cyberspace may not constitute a "search" or "seizure" within the meaning of the Fourth Amendment if "reasonable expectations of privacy" attach only to certain physical places like the home or, even worse, protect only against physical trespasses.

Many people, of course, use the internet from their own homes. Many others do so from their office, and while offices do not "share the Fourth Amendment sanctity of the home," the Supreme Court has consistently treated them as places where people typically have reasonable expectations of privacy. $^{263}$ But a significant and steadily increasing portion of internet use takes place through mobile devices.

More important, Kyllo leaves unclear whether even people who use the internet at home can count on the Fourth Amendment protecting their privacy online. The reason is the Court's equivocation in Kyllo about the significance of possible private surveillance. When announcing that the Fourth Amendment protects against any use of "sense-enhancing technology" to gather information that otherwise would require physical entry into a home, the Court was quick to add a caveat: "at least where (as here) the technology in question is not in general public use."264 The Court repeated the caveat toward the end of its opinion: obtaining information about the inside of a home that previously would have required physical intrusion is a "search" within the meaning of the Fourth Amendment "[w]here, as here, the Government uses a device that is not in general public use."265

A signal and well-known feature of the internet is its vulnerability to "hacking": private, unauthorized monitoring and in some cases manipulation. Of course internet service providers have developed ever more sophisticated protections for the privacy of their users, but each new level of security seems

261 See, e.g., Kang, supra note 254, at 1201 n.20, 1224-29.

200 Kyllo, 533 U.S. at 37.

263 See, e.g., O'Connor v. Ortega, 480 U.S. 709 (1987); Katz, 389 U.S. at 351$52,359$.

264 Kyllo, 533 U.S. at 34.

${ }^{265}$ Id. at 40 (emphasis added). 
inevitably to be defeated by a loose, worldwide network of computer-savvy adolescents. Hacking seems here to stay. ${ }^{266} \mathrm{Kyllo}$ leaves unclear how "general" public use of a monitoring technique must be before its use by the government will escape Fourth Amendment regulation, or even whether "general public use" on any scale will have this effect. ${ }^{267}$ It therefore leaves open the possibility that continued, widespread hacking-or simply widespread use of programs that can be employed for hacking-will render even internet use from the home or office unprotected by the Fourth Amendment, as long as the government is content to use the same sorts of tools that hackers use. ${ }^{268}$

The caveat in Kyllo about "general public use" is plainly important for other reasons, as well. It could eventually strip Fourth Amendment protection from all sorts of things and activities in the home, not just online activity. Doubtless this is why the Court equivocated, saying its new rule applies "at least where ... the technology is not in general public use." ${ }^{269}$ But sooner or later the Court will need to decide whether "general public use" does in fact render a device immune from Fourth Amendment regulation. It therefore would be wise for the rest of us to start considering now what answer the Court should give.

206 See, e.g., Note, supra note 248, at 1595 (noting that all available methods of "securing privacy in cyberspace" are "limited by the fact that the system administrator who runs the typical Internet user's local area network is technologically capable of monitoring all information transmitted into or out of the network"). Indeed, even computers unconnected to the internet are vulnerable to hacking when they are parts of wireless local networks. The New York Times recently reported the emergence of a subculture of hackers "who enter poorly safeguarded wireless networks while driving or walking around with laptops." John Schwartz, Nanny-Cam May Leave a Home Exposed, N.Y. TnMES, Apr. 14, $2002, \S 1$, at $1,27$.

${ }^{267}$ Justice Stevens noted this ambiguity in his dissent, and called "somewhat doubtful" the "assumption that the thermal imager in this case does not satisfy [the] criterion" of "general public use." Kyllo, 533 U.S. at 47 (Stevens, J., dissenting); see infra note 281 and accompanying text.

${ }^{268}$ This prospect is particularly troubling given the proliferating use of the internet for private, visual monitoring of homes by their owners or occupants. See, e.g., Schwartz, supra note 266.

${ }^{200}$ Kyllo, 533 U.S. at 34. 


\section{2. "Reasonable Expectations of Privacy" and Technology in "General Public Use"}

It is easy to understand why the Court left the question of "general public use" for another day. On the one hand, it seems pointless to bar the government from seeing something everyone can see. How can someone have a "reasonable expectation of privacy" in information shared with the public? That intuition explains why the Court in Katz said that "[w]hat a person knowingly exposes to the public, even in his own home or office, is not a subject of Fourth Amendment protection." 270 The same intuition has led the Court to rule, for example, that a homeowner has no expectation of privacy in parts of his backyard that can be observed overhead from "public navigable airspace." ${ }^{.271}$ And the same intuition led the four dissenters in Kyllo to complain that "public officials should not have to avert their senses or their equipment from detecting emissions in the public domain." 272

On the other hand, declaring any device in "general public use" unregulated by the Fourth Amendment would mean that, as technology advances and is disseminated, the zone of privacy preserved by the Constitution will steadily contract. The task the majority set for itself in Kyllo was precisely to identify limits on the "power of technology to shrink the realm of guaranteed privacy," in order to "assure[] preservation of that degree of privacy against government that existed when the Fourth Amendment was adopted." ${ }^{\text {273 }}$ But as Justice Stevens pointed out in dissent, "it seems likely that the threat to privacy will grow, rather than recede, as the use of intrusive equipment becomes more readily available." ${ }^{274}$ So a "general public use" exception could allow technological development to devour much of the Fourth Amendment.

\footnotetext{
270 Katz, 389 U.S. at 351.

271 California v. Ciraolo, 476 U.S. 207, 213-14 (1986).

372 Kyllo, 533 U.S. at 45 (Stevens, J., dissenting).

273 Id. at 34.

274 Id. at 47 (Stevens, J., dissenting).
} 
A case in point: telephones. When cordless telephones proliferated in the 1980 s and early 1990 s, lower courts overwhelmingly concluded that, notwithstanding Katz, conversations conducted on the new devices were unshielded by the Fourth Amendment. Courts reasoned that such conversations could be, and sometimes were, intercepted by anyone with an AM/FM radio-or, when cordless telephones became more sophisticated, with radio scanners "commercially available at most radio and electronics stores. "275 The problem, as one court recognized, is that we may be "moving inexorably toward a completely cordless telephone system," so "the decision as to whether cordless telephone conversation is protected by the Fourth Amendment may ultimately determine whether any telephone conversation is protected by the Fourth Amendment." ${ }^{276}$ In 1994, Congress solved this problem for the time being by statutorily prohibiting warrantless interception of conversations carried out on cordless telephones. ${ }^{277}$ Even without this statute, it is possible, although not certain, that the technological protections of privacy built into cordless telephones-e.g., scrambling circuitry-will improve faster than the tools widely available for circumventing them. ${ }^{278}$ Still, it remains "sobering" that constitutional protections for the confidentiality of telephone conversation might be extinguished by a

275 United States v. Smith, 978 F.2d 171, 173 n.1 (5th Cir. 1992); see also, e.g.,United States v. Carr, 805 F. Supp. 1266 (E.D.N.C. 1992); Chandler v. State, 680 So.2d 1018 (Ala. Crim. App. 1996); People v. Chavez, 52 Cal. Ct. Rptr. 2d 347 (Cal. App. 1996). Early-generation radio telephones for use in automobiles were deemed unprotected on similar grounds. See, e.g., United States v. Hall, 488 F.2d 193 (9th Cir. 1973); United States v. Hoffa, 436 F.2d 1243 (7th Cir. 1970). Similar scanners now can and are used to intercept radio signals sent by "nannycams" to receivers attached to personal computers. See Schwartz, supra note 266.

${ }^{276}$ Smith, 978 F.2d at 177. The unusually thoughtful opinion in Smith suggested in dicta that "as technological advances make cordless communications more private at some point such communication will be entitled to Fourth Amendment protection," but it rejected the Fourth Amendment claim in the case at bar because the defendant "introduced absolutely no evidence-such as the phone's frequency or range-that would tend to show that his subjective expectation of privacy was reasonable." Id. at 180-81.

${ }_{277}$ See 18 U.S.C. $\$ 2510(1)$, (12) (West 2000); see, e.g., Price v. Turner, 260 F.3d 1144, 1147-48 (9th Cir. 2001).

${ }^{278}$ See, e.g., Smith, 978 F.2d at 179. 
widespread risk of private surveillance made possible by new technology. ${ }^{279}$ Another technology-air travel-has already removed such protection for the privacy of most backyards, and the global traffic in software for hacking might leave government monitoring of internet communications unregulated by the Fourth Amendment. ${ }^{280}$

Of course some of this problem could be avoided by a sufficiently narrow definition of "general public use." Perhaps the Court had in mind not devices like radio scanners, which although "commercially available" are still something of a specialty item, but rather things like binoculars and telescopes. But a concept like "general public use" is difficult to cabin; that is why the dissenters in Kyllo could plausibly suggest that the thermal imager used in the case before the Court might satisfy the majority's criterion. ${ }^{281}$ More important, even devices as mundane as binoculars and telescopes, if left constitutionally unregulated, could do significant damage to the "degree of privacy against the government that existed when the Fourth Amendment was adopted." ${ }^{282}$ That is why several lower courts

${ }^{279}$ Id. at 177. The Fifth Circuit noted in Smith that "[t]he equipment needed to tap a regular telephone line can be purchased for less than $\$ 25$ at Radio Shack." Id. at 179 n.10 (emphasis added). Surely, the court reasoned, this does not mean that without statutory prohibitions on wiretapping the Fourth Amendment would not protect land line telephones. Id. One would hope not. But the Supreme Court has left the matter in doubt, in part by equivocating as it did in Kyllo about the significance of "general public use" of devices that can be used for surveillance.

280 The majority in Kyllo seemed aware of the problem, and stressed that the "general public use" doctrine was not of its own making, but rather followed from the Court's previous treatment of observations from airplanes. See Kyllo, 533 U.S. at 39 n.6. Kyllo was not the proper case for reconsidering the doctrine, the majority suggested, because "we can quite confidently say that thermal imaging is not 'routine." Id.

${ }^{281}$ See id. at 47 (Stevens, J., dissenting).

The record describes a device that numbers close to a thousand manufactured units; that has a predecessor numbering in the neighborhood of 4,000 to 5,000 units; that competes with a similar product numbering from 5,000 to 6,000 units; and that is 'readily available to the public' for commercial, personal, or law enforcement purposes, and is just an 800number away from being rented from 'half a dozen national companies' by anyone who wants one.

Id. at 2050 n.5.

228 Kyllo, 533 U.S. at 34. 
(although certainly not all) have found the Fourth Amendment triggered by the use of binoculars or telescopes to spy on suspects in their own homes. ${ }^{283}$ As one court explained, leaving this kind of intrusion into the home constitutionally unrestricted "would violate the basic foundations of privacy, security and decency which distinguish free societies from controlled societies."284 That intuition seems sound-as does the similar notion that the Fourth Amendment should have something to say about when the police can use binoculars or telescopes to read the lips of someone speaking on a public telephone, or to intercept a text message displayed on a wireless communication device. None of these intuitions are easy to defend, though, if "general public use" of binoculars and telescopes means their employment by the government can violate no reasonable expectation of privacy. And if any means of sensory enhancement are "general public use," binoculars and telescopes are. ${ }^{285}$

There are two relatively straightforward ways out of this dilemma, but both would require the Supreme Court to rethink certain aspects of Fourth Amendment law. ${ }^{286}$ The first and

${ }^{28 s}$ See, e.g., United States v. Taborda, 635 F.2d 131 (2d Cir. 1980); United States v. Kim, 415 F. Supp. 1252 (D. Haw. 1976); Wheeler v. State, 659 S.W.2d 381 (Tex. Crim. App. 1982). But see, e.g., State v. Ludvik, 698 P.2d 1064 (Wash. Ct. App. 1985); People v. Clark, 350 N.W.2d 754 (Mich. App. 1983); Cooper v. Superior Court, 173 Cal Rptr. 520 (Cal. Ct. App. 1981). For a helpful overview of the cases, see Kate Donovan Reynaga, Annotation, Observation Through Binoculars as Constituting Unreasonable Search, 59 A.L.R. 5th 615 (1998).

${ }^{284}$ Kim, 415 F. Supp. at 1257; accord, Lawrence Kaiser Marks, Note, Telescopes, Binoculars, and the Fourth Amendment, 67 CORNELL L. REV. 379, 394 (1982).

${ }^{285}$ But see Marks, supra note 284, at 393 (reasoning that "[b]ecause the use of telescopes and binoculars is not widespread in our society, citizens maintain a reasonable expectation of privacy for activity and objects not readily observable by the naked eye").

${ }^{286}$ Under each of these proposals, "reasonable expectations of privacy" would remain the chief objects of Fourth Amendment protection. Plausible arguments can be made that search-and-seizure law should instead focus first and foremost on protecting something other than privacy-e.g., "security," see Clancy, supra note 67, at 344-69, or "trust," see Scott E. Sundby, "Everyman"s Fourth Amendment: Privacy or Mutual Trust Between Government and Citizen, 94 ColuM. L. REV. 1751 (1994). But any sensible approach to the Fourth Amendment will likely incorporate concepts of privacy at some level. Professor Clancy, for example, finds the essence of the Fourth Amendment in "the ability and the right to exclude agents of the government," but he stresses that "It]he ability to exclude must 
simplest way out would be to recognize that government surveillance differs from private snooping, and therefore that the latter, no matter how common, should not eliminate protection against the former. This was the approach one lower court took when it found that government agents intruded on a reasonable expectation of privacy by using a telescope to peer into a suspect's apartment. ${ }^{287}$ The court expressly rejected the government's claim that any expectation of privacy was rendered unreasonable by the widespread use of telescopes by private citizens to spy on people living in high-rises. ${ }^{288}$ Private snooping, the court reasoned, had "no bearing" on the legality of government surveillance, because the government spies "for different purposes than private citizens," and sometimes "with more zeal." Accordingly, a person's "lack of concern about intrusions from private sources has little to do with an expectation of freedom from systematic governmental surveillance," and "[ $t]$ he fact that Peeping Toms abound does not license the government to follow suit."290

There obviously is a good deal to be said for this line of thinking. ${ }^{291}$ But the Court has consistently rejected it. Katz it-

extend to all invasions, tangible and intangible, and must protect both tangible and intangible aspects of the amendment's protected objects." Clancy, supra note 67, at 367. It is difficult to see how "intangible" invasions can be defined without drawing on some notion of privacy. Professor Sundby urges the Court to pay attention in Fourth Amendment cases to "how government intrusions affect the underlying need for government-citizen trust." Sundby, supra, at 1755. Again, though, some concept of privacy seems necessary in order to identify government "intrusions" in the first place. Sundby in fact proposes that considerations of trust supplement, not replace, considerations of privacy in Fourth Amendment law. See, e.g., id. at 1754-55.

${ }_{287}$ Kim, 415 F. Supp. at 1256.

288 Id.

289 Id.

200 Id.

${ }^{291}$ Cf., e.g., Litman, supra note 258 , at 1309 (“[1]nformation . . . is disclosed [within many commercial relationships] subject to implicit constraints of confidentiality. . . . People give merchants sensitive information ... in order to consummate commercial transactions, believing the information will be used only for that purpose and then discarded."); Sundby, supra note 286, at 1793 ("The early morning banging of the trash cans becomes the same whether one looks out the window and sees a bored sanitation worker or a police officer searching for criminal evidence. Does the Fourth Amendment really not see the difference?"); Tomkovicz, supra note 226, at 728-29 (" $[\mathrm{E}]$ xpressive and associational rights demand both 
self denied Fourth Amendment protection to anything "a person knowingly exposes to the public, even in his own home or office." ${ }^{292}$ Later the Court the suggested more broadly that exposing information even to a limited number of "third parties" eliminates any reasonable protection of privacy against the government. ${ }^{293}$ It was partly on this basis that the Court found no reasonable expectation of privacy in numbers dialed on a telephone and transmitted to the telephone company, ${ }^{294}$ information conveyed to a bank, ${ }^{295}$ garbage left for curbside collection, ${ }^{296}$ or statements made to someone who turns out to be a government informant. ${ }^{297}$ Plainly there must be limits to this broader principle; otherwise no conversations would ever be protected by the Fourth Amendment. But the Court has never deviated from the narrower position, reflected in $\mathrm{Katz}$, that sharing information with "the public" renders any expectation of privacy "unreasonable" and hence constitutionally unprotected.

There is a second way out of the dilemma created by the caveat in Kyllo about "general public use." Instead of giving effect to the qualitative differences between government surveillance and private snooping, the Court could simply take account of legal prohibitions on private snooping. In most places in the United States, after all, there are laws against intercepting your neighbor's telephone calls, breaking into his e-mail account, or using binoculars or a telescope to spy on him in his

disclosure to others and a measure of protected confidentiality with respect to the government. ... [T] multaneous presence of those two foundational requirements.")

${ }^{292} \mathrm{Katz}, 389$ U.S. at 351.

290 Smith v. Maryland, 442 U.S. 735, 743-44 (1979); see Burkoff, supra note 60, at 537-38.

294 See Smith, 442 U.S. at 743-44.

295 See United States v. Miller, 425 U.S. 435, 443 (1976).

296 See California v. Greenwood, 486 U.S. 35 (1988).

297 See United States v. White, 401 U.S. 745 (1971). For evidence that these rulings run counter to "societal perceptions of intrusiveness," see Slobogin \& Schumacher, supra note 255 , at $734,738-40$. See also Litman, supra note 258 , at 1307, 1309 (noting that "customers expect the merchants they patronize to respect their privacy," and that "It]he fact that businesses respond to consumer privacy complaints with defensive apologies" suggests that they "are aware of, intentionally cultivate, and may even to some extent share" that understanding). 
own house. Those laws reflect collective decisions about the proper bounds of privacy, and they in turn help to make those bounds real. So perhaps "general public use" in Kyllo should be read to mean widespread and lawful use of a device to see or hear the same things the government seeks to see or hear. Perhaps government use of binoculars, telescopes, radio scanners or hacking software should constitute a search at a minimum in those circumstances where private citizens are legally prohibited from using the similar devices to spy on one another.

The Supreme Court, though, has repeatedly suggested that local tort and property laws are all but irrelevant in assessing whether particular expectations of privacy are "reasonable" and hence constitutionally protected. ${ }^{298}$ Garbage searches, for example, are not "searches" within the meaning of the Fourth Amendment, even when they are employed to discover what is occurring within a residence, and even when local laws prohibit similar intrusions by private citizens. ${ }^{299}$ In part this ruling reflected the Court's reluctance-elsewhere reiterated but never fully explained-to allow Fourth Amendment rights to vary from one part of the country to another. ${ }^{300}$ But in part it also reflected broader trends in search-and-seizure jurisprudence: the rejection of the "trespass theory" of the Fourth Amendment, and later the return to common law. For much of the past several decades, tying reasonable expectations of privacy to tort and property protections has seemed archaic, ${ }^{301}$ a throwback to the discarded underpinnings of Olmstead $v$. United States. ${ }^{302}$ Recently the Court has become much less interested

298 See Greenwood, 486 U.S. at 43-44; Oliver v. United States, 466 U.S. 170, 183-84 (1984); Bivens v. Six Unknown Named Agents, 403 U.S. 388, 393-94 (1971); Mancusi v. DeForte, 392 U.S. 364, 368 (1968); Daniel B. Yeager, Search, Seizure, and the Positive Law: Expectations of Privacy Outside the Fourth Amendment, 84 J. CrIM. L. \& CRIMINology 249 (1993).

290 See Greenwood, 486 U.S. at $43-44$.

300 See id. at 44; see also Whren v. United States, 517 U.S. 806, 815 (1996) (refusing to allow Fourth Amendment protections to "vary from place to place and from time to time"); Bivens, 403 U.S. at 393-94 (explaining that "the Fourth Amendment is not tied to the niceties of local trespass laws").

${ }^{301}$ See Yeager, supra note 298, at 250-51, 265-69.

sos 277 U.S. 438 (1938); see supra text accompanying notes 24-31. 
in modernizing Fourth Amendment law and more interested in making it stable and predictable. But in returning to common law the Court has sought to insulate the Fourth Amendment not only against changing views of judges but also changing views of legislatures. ${ }^{303}$ From this perspective, too, modern rules of tort and property-constantly subject to the tinkering of judges and legislatures-seem a poor anchor for Fourth Amendment rights.

Plainly, the zone of privacy protected by the Fourth Amendment cannot be defined in its entirety by reference to transitory, sub-constitutional rules of property and tort. Even if private citizens can eavesdrop lawfully on conversations carried out on portable telephones, that should not mean the government can do so without any constitutional limitations. Government surveillance is different than private snooping, not only because it tends to be carried out in different ways and for different purposes, but because the government poses specials kinds of threats. ${ }^{304}$ So the legality of private snooping, like its technical feasibility, should not by itself mean that similar snooping by government agents violates no reasonable expectation of privacy. But when private snooping is illegal, there is even less reason to allow its technical feasibility to render government surveillance immune from constitutional restrictions. ${ }^{305}$

sos See County of Riverside v. McLaughlin, 500 U.S. 44, 60 (1991) (Scalia, J., dissenting); Sklansky, supra note 12, at 1793.

so4 See, e.g., David A. Sklansky, The Private Police, 46 UCLA L. REv. 1165, 1271 (1999); Slobogin, supra note 68, at 429.

In addition, Fourth Amendment law and restrictions on private snooping may currently share some blind spots that Fourth Amendment law would be better off without. For example, Fourth Amendment law probably should take much more account than it currently does of how the government uses what it learns through surveillance. See supra note 105 and accompanying text. But this defect cannot be remedied by borrowing from tort doctrines regarding invasion of privacy, because those doctrines themselves pay only slightly more attention than Fourth Amendment law to how lawfully gathered information is disseminated. See, e.g., Litman, supra note 258, at 1291 .

sos See Yeager, supra note 298, at 251-52 (suggesting that "[o]nly when the positive law recognizes no privacy interest in a given case need we resort to Katz, which certainly may recognize a privacy interest that the positive law has missed, but cannot be used to overcome a privacy interest that the positive law 
The majority's caveat in Kyllo about technology in "general public use" thus flags a real problem in Fourth Amendment doctrine, and a problem the Court would be wise to address in two different ways. In the long term, sensible interpretation of the Fourth Amendment will require the Court to acknowledge the differences between government surveillance and private snooping, and to abandon the assumption that anything knowingly exposed "to the public" is therefore fair game for the police. In the short term, while the Court continues to make this assumption, it should at least reconsider its refusal to take property and tort law into account in assessing whether particular expectations of privacy are "reasonable" and therefore deserve constitutional protection. Pointing the Court in these directions is one of the ways in which Kyllo may help the Justices bridge more sensibly the past of the Fourth Amendment and its future.

\section{CONCLUSION}

Kyllo is a promising decision. It recognizes not only the ways in which new technology can erode a traditional sphere of privacy, but also the need for Fourth Amendment jurisprudence to focus simultaneously on the past, the present, and the future. It preserves the most important holding of Katz, that a "search" or "seizure" does not require a physical trespass, while wisely insisting that some "places"-in particular, homes-have special status under the Fourth Amendment. It uses common law more loosely and more sensibly than other recent decisions of the Supreme Court. And by leaving open the possibility that even technology in "general public use" may constitute a search if used to peer into homes, it provides an opportunity for the Court to reconsider certain aspects of search-and-seizure law that could amply benefit from reconsideration. Whether Kyllo ultimately proves a step forward or a step back will depend in part on what use the Court makes of those opportunities. It

has identified"); cf. Tomkovicz, supra note 226, at 694 (noting that "[p]roperty notions and 'intrusions' may well be pertinent and useful elements in evaluating fourth amendment privacy claims," but cautioning against the "automatic invocation of these criteria across the board"). 
will also depend whether the Court keeps in mind that the home is not the only place where privacy deserves protection, and that reasonable expectations of privacy can attach to communications as well as to locations. And it will depend on how comfortable the Court remains with the burden of judgment entailed in taking "the long view, from the original meaning of the Fourth Amendment forward. ${ }^{n 306}$ 
HeinOnline -- 72 Miss. L.J. 212 2002-2003 